- Faktor - faktor Yang Mempengaruhi Kinerja Transaksi Berjalan Indonesia

- Indonesian Japan Economic Relations : (Investment and Trade)

- Analisis Kinerja Industri TPT Indonesia

- Kajian Atas Perlakuan Akuntansi Terhadap Skema Perdagangan Emisi (Emission Trading Scheme) Pelajaran Dari Uni Eropa dan Australia

- Kajian Kebijakan PPN Atas Bahan Bakar Minyak Untuk Kapal Tujuan Internasional (Study on Value Added Tax Policy on International Bunker Fuen

\begin{tabular}{|c|c|c|c|c|c|}
\hline Kaj. Eko. \& Keu. & Vol. 14 & No. 4 & Jakarta 2010 & $\begin{array}{c}\text { ISSN 1410- } \\
3249\end{array}$ & $\begin{array}{c}\text { Terakreditasi B } \\
\text { (No. Akreditasi : } \\
\text { 306/AU2/P2MBI/08/2010) }\end{array}$ \\
\hline
\end{tabular}




\section{K A J I A N}

EKONOMI

KEUANGAN

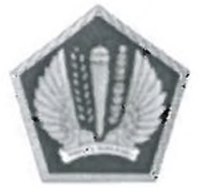

Pusat Kebijakan Ekonomi Makro

Badan Kebijakan Fiskal

Kementerian Keuangan RI

Faktor-faktor Yang Mempengaruhi Kinerja Transaksi

Berjalan Indonesia

(5)

Indonesia Japan Economic Relations: (Investment and Trade)

2

Analisis Kinerja Industri TPT Indonesia

证

Kajian Atas Perlakuan Akuntansi Terhadap Skema

Perdagangan Emisi (Emission Trading Scheme)

Pelajaran dari Uni Eropa dan Australia

Kajian Kebijakan PPN Atas Bahan Bakar Minyak. Untuk Kapal

Tujuan Internasional (Study On Value Added Tax Policy On Internasional Bunker Fuel)

\begin{tabular}{|l|l|l|l|l|}
\hline Kaj. Eko. \& Keu. & Vol. 14 & No.4 & Jakarta 2010 & ISSN 1410-3249 \\
\hline
\end{tabular} 


\section{KATA SAMBUTAN}

Kami panjatkan rasa syukur kepada Tuhan Yang Maha Esa atas terbitnya Kajian Ekonomi dan Keuangan edisi ini ke hadapan pembaca sekalian. Pada edisi ini, kami menyajikan berbagai topik yang berkaitan dengan analisis dan dampak kebijakan publik di bidang ekonomi dan keuangan negara.

Kajian pada volume kali ini diisi oleh berbagai topik tulisan yaitu FaktorFaktor yang Mempengaruhi Kinerja Transaksi Berjalan Indonesia; Indonesia Japan Economic Relations:(Investment and Trade); Analisis Kinerja Industri TPT Indonesia; Kajian Atas Perlakuan Akuntansi Terhadap Skema Perdagangan Emisi (Emission Trading Scheme) Pelajaran Dari Uni Eropa Dan Australia; dan Kajian Kebijakan PPN Atas Bahan Bakar Minyak Untuk Kapal Tujuan Internasional (Study On Value Added Tax Policy On Internasional Bunker Fuel). Adapun para penulis yang berkontribusi pada penerbitan kali ini yaitu Rudi Handoko, Suparman Zen Kemu, Ragimun, Mahpud Sujai, dan I Nyoman Widia.

Demikianlah kata pengantar yang dapat kami sampaikan. Ibarat peribahasa tiada gading yang tak retak, maka kami menyadari kajian ini tentunya masih terdapat kekurangan baik yang disengaja maupun yang tidak kami sengaja. Oleh karena itu, kami mengharapkan masukan dari para pembaca guna perbaikan di masa yang akan datang. Selanjutnya, kami berharap jurnal ini dapat memberikan manfaat kepada para pembaca sekalian. Selamat membaca!

Jakarta, 2010

Dewan Redaksi 



\section{DAFTAR ISI}

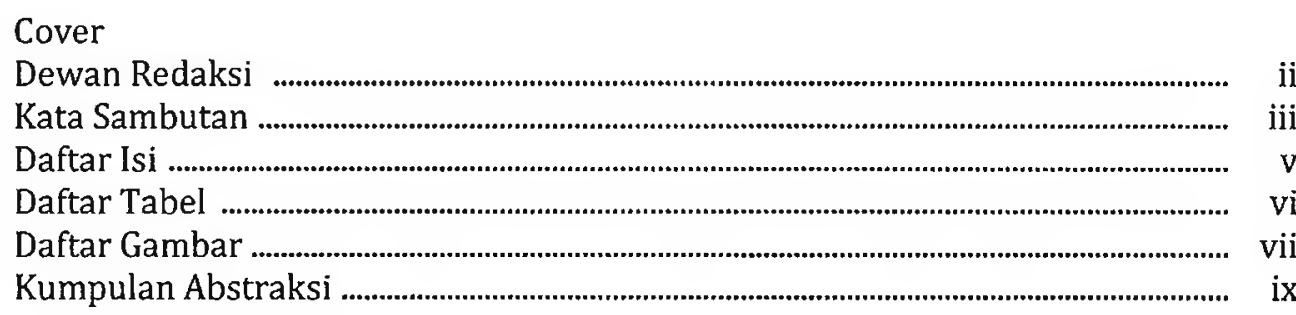

FAKTOR-FAKTOR YANG MEMPENGARUHI KINERJA TRANSAKSI

BERJALAN INDONESIA

Oleh: Rudi Handoko

INDONESIA JAPAN ECONOMIC RELATIONS:

(INVESTMENT AND TRADE)

Oleh: Suparman Zen Kemu

\section{ANALISIS KINERJA INDUSTRI TPT INDONESIA}

Oleh: Ragimun

\section{KAJIAN ATAS PERLAKUAN AKUNTANSI TERHADAP SKEMA \\ PERDAGANGAN EMISI (EMISSION TRADING SCHEME) \\ PELAJARAN DARI UNI EROPA DAN AUSTRALIA}

Oleh: Mahpud Sujai

KAJIAN KEBIJAKAN PPN ATAS BAHAN BAKAR MINYAK

UNTUK KAPAL TUJUAN INTERNASIONAL (STUDY ON VALUE ADDED

TAX POLICY ON INTERNATIONAL BUNKER FUEL)

Oleh: I Nyoman Widia 


\section{DAFTAR TABEL}

INDONESIA JAPAN ECONOMIC RELATIONS: (INVESTMENT AND TRADE)

Tabel 2.1. Japanese Foreign Investment Destination

\section{ANALISIS KINERJA INDUSTRI TPT INDONESIA}

Tabel 3.1. Profil Industri TPT Indonesia tahun 2004-2008...................................... 50

Tabel 3.2. Program Peningkatan Kinerja Industri TPT ............................................ 53

Tabel 3.3. Faktor-Faktor Yang Mempengaruhi Daya Saing Industri TPT Indonesia dengan China 57

Tabel 3.4. Struktur Biaya Tekstil dan Produk Tekstil (\%) 58

KAJIAN ATAS PERLAKUAN AKUNTANSI TERHADAP SKEMA

PERDAGANGAN EMISI (EMISSION TRADING SCHEME)

PELAJARAN DARI UNI EROPA DAN AUSTRALIA

Tabel 1.1. GHG Emissions Summary(MtCO2e)

\section{KAJIAN KEBIJAKAN PPN ATAS BAHAN BAKAR MINYAK} UNTUK KAPAL TUJUAN INTERNASIONAL (STUDY ON VALUE ADDED TAX POLICY ON INTERNASIONAL BUNKER FUEL)

Tabel 1.1. Penerimaan Perpajakan 2005 - 2010 (Triliun Rupiah) 78

Tabel 3.1. Perbandingan Penjualan BBM Indonesia dan Singapura (kilo liter) 


\section{DAFTAR GAMBAR}

\section{FAKTOR-FAKTOR YANG MEMPENGARUHI KINERJA TRANSAKSI BERJALAN INDONESIA}

Gambar 3.1. Neraca Transaksi Berjalan dan Neraca Perdagangan 1960 - 1979

(US\$ juta)

Gambar 3.2. Ekspor Minyak dan Bukan Minyak 1960 - 1979

(US\$ juta)

Gambar 3.3. Neraca Transaksi Berjalan dan Neraca Perdagangan 1980 - 1991 (US\$ juta)

Gambar 3.4. Ekspor Minyak dan Gas 1980 - 1991 (US\$ juta) 10

Gambar 3.5. Komponen Neraca Transaksi Berjalan 1992 - 2003 (US\$ juta)

Gambar 3.6. Neraca Transaksi Berjalan dan Neraca Perdagangan $1992-2003$ (US\$ juta)

Gambar 3.7. Neraca Transaksi Berjalan dan Neraca Perdagangan Q1 2004 - Q2 2010 (US\$ juta)

Gambar 3.8. Neraca Transaksi Berjalan dan Neraca Perdagangan Non Migas Q1 2004 - Q2 2010 (US\$ juta). 14

Gambar 3.9. Neraca Transaksi Berjalan dan Neraca Perdagangan Migas Q1 2004 - Q2 2010 (US\$ juta)

Gambar 3.10. Neraca Transaksi Berjalan dan Neraca Perdagangan Minyak Q1 2004 - Q2 2010 (US\$ juta)

Gambar 3.11. Neraca Transaksi Berjalan dan Neraca Perdagangan Gas Q1 $2004-$ Q2 2010 (US\$ juta)

Gambar 3.12. Neraca Transaksi Berjalan dan Jasa-jasa Q1 2004 - Q2 2010 (US\$ juta) 17

Gambar 3.13. Neraca Transaksi Berjalan dan Pendapatan Q1 2004 - Q2 2010 (US\$ juta) 18

Gambar 3.14. Neraca Transaksi Berjalan dan Transfer Q1 2004 - Q2 2010 (US\$ juta) 18

Gambar 3.15. Hubungan Transaksi Berjalan dan Pertumbuhan Ekonomi Domestik

Gambar 3.16. Hubungan Transaksi Berjalan dan Pertumbuhan Ekonomi Dunia

Gambar 3.17. Transaksi Berjalan dan Harga Komoditas. 21

Gambar 3.17. Transaksi Berjalan dan Nilai Tukar 22 
INDONESIA JAPAN ECONOMIC RELATIONS: (INVESTMENT AND TRADE)

Graph 2.1. Indonesian non-oil exports by destination country (US\$ billion)

Graph 2.2. Indonesia Japanese import and export (Billion Yen).

\section{ANALISIS KINERJA INDUSTRI TPT INDONESIA}

Grafik 3.1. Jumlah Perusahaan dan Jumlah Share Industri TPT

Tahun 2008-2009 


\begin{tabular}{|c|}
\hline $\begin{array}{l}\text { MAJALAH KAJIAN EKONOMI DAN KEUANGAN } \\
\text { ISSN 1410-3249 } \\
\text { KEK Terakreditasi B } \\
\text { (No. Akreditasi : 306/AU2/P2MBI/08/2010) } \\
\text { Volume 14 Nomor 4 Tahun } 2010\end{array}$ \\
\hline $\begin{array}{c}\text { Keywords used are free terms. Abstracts can be reproduced without } \\
\text { permission or charge. }\end{array}$ \\
\hline ABSTRAKSI \\
\hline $\begin{array}{l}\text { Handoko, Rudi, et. al. (Badan Kebijakan Fiskal, Kementerian Keuangan) } \\
\text { Faktor-Faktor Yang Mempengaruhi Kinerja Transaksi Berjalan Indonesia } \\
\text { Kajian Ekonomi dan Keuangan Volume } 14 \text { Nomor } 4 \text { Tahun 2010, halaman } \\
\text { 1-24 }\end{array}$ \\
\hline $\begin{array}{l}\text { This paper attempt to describe factors affecting the performance of current } \\
\text { account in Indonesia. Current account performance is showed by surplus or } \\
\text { deficit position. Analysis of the factors is conducted based on periodization of } \\
\text { current account performance. Other analysis was carried out by using scatter } \\
\text { graph to show the relationship between two variables in question. The results } \\
\text { show that some factors affecting current account performance are global } \\
\text { economic growth, Indonesian major trading partners growth, domestic } \\
\text { economic growth, international commodities prices, exchange rate } \\
\text { management, economic policy, and financial crisis. } \\
\text { Keyword: current account, balance of payment, externalsector, trade } \\
\text { balance }\end{array}$ \\
\hline $\begin{array}{l}\text { Zen Kemu, Suparman, et. al. (Badan Kebijakan Fiskal, Kementerian } \\
\text { Keuangan) } \\
\text { Indonesia Japan Economic Relations: (Investment and Trade) } \\
\text { Kajian Ekonomi dan Keuangan Volume } 14 \text { Nomor } 4 \text { Tahun 2010, halaman } \\
25-40\end{array}$ \\
\hline $\begin{array}{l}\text { Pra krisis ekonomi 1998, Indonesia merupakan Negara urutan ketiga dalam } \\
\text { tujuan investasi langsung Jepang (FDI), dibawah China dan Amerika Serikat. } \\
\text { Namun, paska krisis ekonomi } 1998 \text { tersebut, posisi Indonesia turun ke } \\
\text { ranking kedelapan dan telah dilewati oleh India, Thailand, Vietnam, Rusia, } \\
\text { dan Brazil. Beberapa faktor yang menyebabkan terjadinya hal ini adalah: } \\
\text { kondisi infrastruktur yang buruk di dalam negeri terutama masalah } \\
\text { perlistrikan, kurangnya kepastian hukum, adanya pajak berganda, fluktuasi }\end{array}$ \\
\hline
\end{tabular}




\begin{tabular}{|c|}
\hline $\begin{array}{c}\text { MAJALAH KAJIAN EKONOMI DAN KEUANGAN } \\
\text { ISSN 1410-3249 } \\
\text { KEK Terakreditasi B } \\
\text { (No. Akreditasi : 306/AU2/P2MBI/08/2010) } \\
\text { Volume 14 Nomor } 4 \text { Tahun } 2010\end{array}$ \\
\hline $\begin{array}{l}\text { Keywords used are free terms. Abstracts can be reproduced without } \\
\text { permission or charge. }\end{array}$ \\
\hline ABSTRAKSI \\
\hline $\begin{array}{l}\text { nilai tukar rupiah yang terlampau tajam, dan lemahnya hubungan antar } \\
\text { industrI (linkage). Dalam perdagangan luar negeri Jepang merupakan } \\
\text { partner dagang terbesar Indonesia. Pada tahun 2007, total perdagangan } \\
\text { Indonesia Jepang mencapai nilai USD 23,6, merupakan yang terbesar di } \\
\text { ASEAN dibandingkan perdagangan Negara anggota ASEAN lainnya } \\
\text { terhadap Jepang. Namun jenis ekspor Indonesia ke Jepang di dominasi oleh } \\
\text { komoditi dasar seperti minyak bumi, gas, bahan tambang, dan produk kayu. } \\
\text { Sementara ekspor Negara anggota ASEAN yang lain ke Jepang seperti } \\
\text { Singapura, Thailand dan Malaysia didominasi produk manufaktur berupa } \\
\text { komponen yang mempunyai nilai tambah lebih tinggi. Gejala lainnya adalah } \\
\text { bahwa ada tendensi peningkatan nilai perdagangan Indonesia dengan dua } \\
\text { Negara Asia Timur yaitu China dan Korea. Hal ini positif bagi Indonesia } \\
\text { namun kurang baik bagi kelanjutan hubungan ekonomi Indonesia Jepang. } \\
\text { Berbagai masalah ini perlu dibicarakan secara lebih serius oleh kedua } \\
\text { Negara agar nilai perdagangan dan investasi Indonesia Jepang dapat lebih } \\
\text { meningkat lagi. }\end{array}$ \\
\hline $\begin{array}{l}\text { Ragimun, et. al. (Badan Kebijakan Fiskal, Kementerian Keuangan) } \\
\text { Analisis Kinerja Industri TPT Indonesia } \\
\text { Kajian Ekonomi dan Keuangan Volume } 14 \text { Nomor } 4 \text { Tahun 2010, halaman } \\
\text { 41-62 }\end{array}$ \\
\hline $\begin{array}{l}\text { Textile industry can be categorized the oldest industry in Indonesia. This is a } \\
\text { significant industry, which provides not only on economic contribution but } \\
\text { also on absorbing employment for the total } 15 \% \text { of all manufacture sectors. } \\
\text { At the present, textile industry is facing some structural problems, such as the } \\
\text { high cost of energy, insufficient of infrastructure, the low technology and } \\
\text { well-worn of the machines, and also the overflowing of China's textiles into } \\
\text { Indonesia markets. Those are causing high cost of production and further } \\
\text { impeding competitiveness of domestic textile in the world market. } \\
\text { On the early stage, the textile industry development was boosted by the } \\
\text { Foreign Investment Law (1967) and the Domestic Investment Law (1968). In } \\
\text { addition, the export quota system grows up steadily during the period of } \\
1984 \text { to } 2000, \text { which reach to } 18,5 \% \text { per year. For the last } 5 \text { years, however, } \\
\text { the export shows a fluctuation. For } 2000 \text {, the number reaches US\$8.3 billion, } \\
\text { and in } 2009 \text { goes to US } \$ 9.26 \text { billion or just a tiny increase of } 3.41 \% \text { per year. }\end{array}$ \\
\hline
\end{tabular}




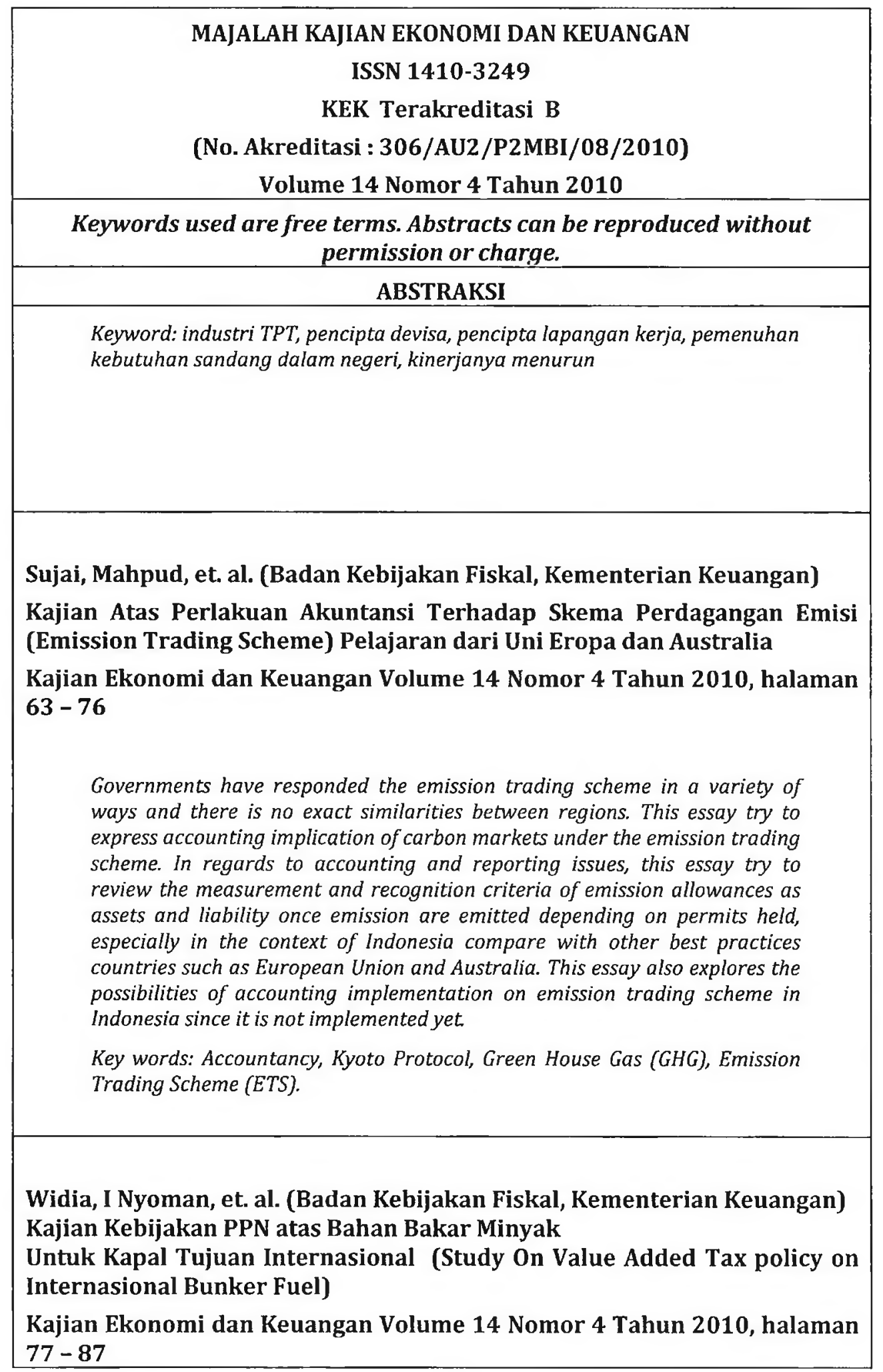


MAJALAH KAJIAN EKONOMI DAN KEUANGAN

ISSN 1410-3249

KEK Terakreditasi B

(No. Akreditasi : 306/AU2/P2MBI/08/2010)

Volume 14 Nomor 4 Tahun 2010

Keywords used are free terms. Abstracts can be reproduced without permission or charge.

ABSTRAKSI

This study focus on value added tax policy on international bunker fuel. Current regulation in Indonesia describes that government has imposed value added tax $10 \%$ on bunker fuel. Qualitative Approach was used in this study. As a result, imposing value added tax on bunker fuel against the international best practice. According to Value Added Tax Law, Government of Indonesia may give an incentive on bunker fuel.

Keywords: value added tax, international bunker fuel, incentive 


\title{
FAKTOR-FAKTOR YANG MEMPENGARUHI KINERJA TRANSAKSI BERJALAN INDONESIA
}

Oleh:

Rudi Handoko 1

\begin{abstract}
This paper attempt to describe factors affecting the performance of current account in Indonesia. Current account performance is showed by surplus or deficit position. Analysis of the factors is conducted based on periodization of current account performance. Other analysis was carried out by using scatter graph to show the relationship between two variables in question. The results show that some factors affecting current account performance are global economic growth, Indonesian major trading partners growth, domestic economic growth, international commodities prices, exchange rate management, economic policy, and financial crisis.
\end{abstract}

Kata kunci: current account, balance of payment, external sector, trade balance

\section{PENDAHULUAN}

\subsection{Latar Belakang}

Krisis keuangan global yang semakin dalam sejak September 2008 memberikan tekanan yang cukup signifikan pada kinerja Neraca Pembayaran Indonesia (NPI). Selama 2008 NPI mengalami defisit sebesar US $\$ 1,9$ miliar, berbeda dari tahun 2007 yang mencatat surplus US\$12,7 miliar. Namun demikian, transaksi berjalan masih mampu mencatat surplus sebesar US\$0,1 miliar atau turun dibandingkan surplus pada 2007 yang sebesar US\$10,5 miliar.

Pada 2008, defisit neraca transaksi berjalan terjadi selama tiga triwulan berturut-turut yaitu triwulan II, III, dan IV dengan nilai defisit masing-masing sebesar US $\$ 1,0$ miliar, US $\$ 0,97$ miliar, dan US $\$ 0,64$ miliar. Ini merupakan defisit neraca transaksi berjalan yang pertama kali terjadi dimana sejak triwulan II 2004 s.d. triwulan I 2008 neraca transaksi berjalan selalu membukukan surplus.

Sementara itu, transaksi modal dan finansial mengalami defisit US $\$ 1,9$ miliar, setelah pada tahun 2007 mencatat surplus sebesar US $\$ 3,6$ miliar. Sejalan dengan perkembangan di atas, jumlah cadangan devisa pada akhir periode turun sebesar US $\$ 5,3$ miliar dari US $\$ 56,9$ miliar menjadi US $\$ 51,6$ miliar.

\footnotetext{
${ }^{1}$ Peneliti Muda pada Pusat Kebijakan Ekonomi Makro, Badan Kebijakan Fiskal, Kementerian Keuangan RI.
} 
Seiring dengan membaiknya prospek ekonomi global dan domestik, kinerja neraca pembayaran tahun 2009 mengalami perbaikan. Neraca transaksi berjalan pada tahun 2009 mencatat surplus US $\$ 10,6$ miliar, yang didorong oleh kenaikan surplus pada neraca perdagangan. Neraca transaksi modal dan finansial pada tahun 2009 mencatat surplus sebesar US $\$ 3,7$ miliar, yang bersumber dari tingginya surplus pada investasi langsung dan investasi portofolio.

Kinerja neraca transaksi berjalan yang dikaitkan dengan posisi surplus atau defisit selalu menjadi perhatian serius pemerintah karena jika terjadi tekanan pada neraca transaksi berjalan akan mempengaruhi posisi cadangan devisa yang pada gilirannya bisa mengganggu stabilitas nilai tukar rupiah.

Sehungan dengan hal tersebut di atas, penulis ingin memaparkan faktorfaktor yang dapat mempengaruhi defisit atau surplus neraca transaksi berjalan serta memberikan kesimpulan dan rekomendasi sebagai bahan masukan bagi pembuatan kebijakan di bidang neraca transaksi berjalan.

\subsection{Permasalahan}

Kinerja transaksi berjalan Indonesia mengalami pasang naik dan pasang surut yang sangat dipengaruhi baik oleh faktor internal maupun faktor eksternal. Pokok permasalahan dalam tulisan ini adalah mengidentikasikan faktor-faktor apa sajakah baik dari sisi kebijakan maupun variabel-variabel ekonomi makro yang dapat mempengaruhi kinerja neraca transaksi berjalan.

\subsection{Tujuan Penulisan}

Tulisan ini bertujuan untuk mengetahui faktor-faktor apa saja yang dapat mempengaruhi defisit atau surplus neraca transaksi berjalan serta memberikan usulan rekomendasi bagi kebijakan di bidang transaksi berjalan.

\subsection{Metode Penelitian}

Dalam analisis ini akan dipergunakan pendekatan analisis deskriptif. Data yang digunakan adalah data sekunder yang bersumber dari Bank Indonesia, CEIC dan Bloomberg. Untuk melengkapi analisis, juga akan dipergunakan data kualitatif yang dikumpulkan dari berbagai sumber seperti makalah ilmiah, majalah, surat kabar maupun sumber lainnya yang relevan. 


\section{KERANGKA TEORI}

\subsection{Pengertian Neraca Pembayaran}

IMF (1996) mendefinisikan neraca pembayaran (balance of payment (BOP)) sebagai laporan statistik yang meringkas secara sistematis, selama periode waktu tertentu, transaksi ekonomi suatu negara dengan negara-negara lainnya. Transaksi antara penduduk (residents) dengan bukan penduduk (nonresidents) meliputi barang, jasa, pendapatan, tranfer serta klaim finansial atas dan kewajiban finansial kepada negara-negara lain.

Tujuan pembuatan statistik Neraca Pembayaran Indonesia (NPI) adalah untuk memperoleh informasi tentang: (1) peranan dan dampak sektor eksternal terhadap perekonomian domestik; (2) aliran sumber daya dari/ke negara lain; (3) struktur ekonomi dan perdagangan internasional; (4) permasalahan utang luar negeri baik pemerintah maupun swasta; (5) perubahan posisi cadangan devisa dan potensi tekanan terhadap nilai tukar; (6) sumber data dan informasi untuk menyusun angaran devisa; serta (7) sumber data dalam penyusunan statistik neraca nasional (Bank Indonesia 2008).

\subsection{Pengertian Transaksi Berjalan}

Menurut Bank Indonesia (2008) transaksi berjalan (current account) mengukur penerimaan dan pengeluaran Indonesia yang berasal dari transaksi barang dan jasa (goods and services), pendapatan (income), dan transfer berjalan (current transfer) dengan bukan penduduk. Komponen transaksi berjalan adalah neraca perdagangan, jasa-jasa, pendapatan, dan transfer berjalan.

Neraca perdagangan adalah transaksi ekspor dan impor barang (komoditas). Sedangkan ekspor dan impor jasa masuk ke dalam neraca jasa-jasa. Neraca jasajasa meliputi transaksi penyediaan jasa oleh penduduk kepada bukan penduduk (arus masuk) dan oleh bukan penduduk kepada penduduk (arus keluar).

Jasa adalah transaksi penyediaan jasa antara penduduk dan bukan penduduk. Ada 11 jenis jasa yang tercantum dalam Neraca Pembayaran Indonesia (NPI) yaitu jasa transportasi, travel, jasa komunikasi, jasa kontruksi, jasa asuransi, jasa keuangan, jasa komputer dan informasi, royalti dan imbalan lisensi, jasa personal, kultural, dan rekreasi, jasa pemerintah, dan jasa bisnis lainnya.

Pendapatan adalah hasil yang timbul dari penyediaan faktor produksi tenaga kerja dan modal finansial. Pendapatan terdiri dari kompensasi tenaga kerja (compensation of employees) dan pendapatan investasi (investment income). Kompensasi tenaga kerja bersumber dari pekerja musiman yang bekerja kurang dari satu tahun. Pendapatan investasi terbagi tiga yaitu pendapatan investasi 
langsung (direct investment income), pendapatan investasi portofolio (portfolio investment income), dan pendapatan investasi lainya (other investment income).

Transfer berjalan mencatat transaksi sepihak yang melibatkan penyerahan sumber daya tanpa timbal balik (contoh hadiah atau hibah). Unsur terbesar pada neraca transfer berjalan adalah remitansi tenaga kerja (workers' remittances). Transfer ini adalah transfer tenaga kerja Indonesia (TKI) di luar negeri.

\subsection{Hubungan Neraca Pembayaran dan Neraca Pendapatan Nasional}

Faktor-faktor yang mempengaruhi surplus atau defisit neraca transaksi berjalan juga dapat dilihat dari hubungan antara neraca pembayaran dan pendapatan nasional. Neraca pendapatan nasional (national account) adalah

$\mathrm{Y}=\mathrm{C}+\mathrm{G}+\mathrm{I}+(\mathrm{X}-\mathrm{M})$

di mana $\mathrm{Y}=$ Produk domestik bruto, $\mathrm{C}=$ konsumsi swasta, $\mathrm{G}=$ konsumsi pemerintah, $\mathrm{I}=$ pembentukan modal tetap bruto, dan $\mathrm{X}-\mathrm{M}=$ neraca perdagangan barang \& jasa (NP).

Dengan asumsi neraca transaksi berjalan hanya merupakan neraca perdagangan barang \& jasa, persamaan (1) dapat disusun ulang menjadi:

$\mathrm{Y}=\mathrm{C}+\mathrm{G}+\mathrm{I}+\mathrm{CA}$

Kemudian, disusun ulang sebagai berikut:

$\mathrm{Y}-(\mathrm{C}+\mathrm{G})=\mathrm{I}+\mathrm{CA}$

Jika $Y-(C+G)=S$, dimana $S=$ Tabungan, sehingga dapat diperoleh:

$\mathrm{S}=\mathrm{I}+\mathrm{CA}$ atau $\mathrm{CA}=\mathrm{S}-\mathrm{I}$

Persamaan (2) merupakan persamaan identitas yang menunjukkan bahwa

jika terjadi surplus transaksi berjalan dimana investasi lebih kecil daripada tabungan, sehingga kebutuhan investasi dapat ditutup melalui tabungan. Sedangkan pada kondisi defisit transaksi berjalan, investasi lebih besar daripada tabungan, sehingga untuk menutup kebutuhan investasi yang besar tersebut diperlukan sumber pendanaan dari luar negeri. Sumber pendanaan luar negeri dalam bentuk utang ini akan dicatat pada pos transaksi modal dan finansial. Adapun hubungan antara transaksi berjalan dan transaksi modal dan finansial adalah:

$\mathrm{CA}+\mathrm{KFA}=$ Saldo Neraca Pembayaran $=$ Perubahan Cadangan Devisa

Persamaan (3) memiliki arti sebagai berikut: jika Saldo Neraca Pembayaran surplus maka cadangan devisa akan bertambah. Sebaliknya jika Saldo Neraca Pembayaran mengalami defisit maka cadangan devisa akan berkurang. 


\subsection{Variabel Ekonomi Makro yang Mempengaruhi Kinerja Transaksi Berjalan}

Calderón, Chong dan Loayza (2000) melakukan penelitian tentang faktorfaktor ekonomi yang mempengaruhi defisit neraca transaksi berjalan di 44 negara berkembang untuk periode 1966-95. Variabel-variabel kunci yang digunakan dalam penelitian tersebut adalah pendapatan, transaksi berjalan, tabungan (publik dan swasta), nilai tukar riil, pengendalian neraca pembayaran, premi pasar gelap nilai tukar, pertumbuhan ekonomi negara industri, dan suku bunga internasional.

Hasil studi Calderón, Chong dan Loayza (2000) menunjukkan bahwa kenaikan pertumbuhan ekonomi domestik menghasilkan defisit neraca transaksi berjalan yang lebih besar, kenaikan tabungan publik atau swasta berdampak positif terhadap neraca transaksi berjalan, apresiasi nilai tukar riil berkaitan dengan defisit neraca transaksi berjalan yang lebih besar, pertumbuhan ekonomi di negara industri yang lebih tinggi atau suku bunga internasional yang lebih tinggi mengurangi defisit neraca transaksi berjalan di negara berkembang.

Dengan menggunakan pendekatan vector autoregression (VAR), Ardiyanto (2006) mencari hubungan antara defisit neraca transaksi berjalan dengan defisit fiskal di Indonesia dengan periode waktu 1981-2004. Berdasarkan kausalitas Granger, defisit neraca transaksi berjalan menyebabkan defisit fiskal tetapi tidak sebaliknya. Adapun variabel makroekonomi seperti nilai tukar, suku bunga dan PDB; variabel suku bunga memiliki pengaruh positif yang mendorong baik defisit neraca transaksi berjalan maupun defisit fiskal.

\subsection{Pengaruh Kebijakan Ekonomi terhadap Kinerja Transaksi Berjalan}

Pengaruh kebijakan ekonomi terhadap kinerja transaksi berjalan dapat dilihat melalui dampaknya pada tabungan dan investasi. Kebijakan ekonomi yang meningkatkan tabungan atau menurunkan investasi (misal, kebijakan kontraksi fiskal) akan mengarah kepada surplus transaksi berjalan, sedangkan kebijakan ekonomi yang menurunkan tabungan atau meningkatkan investasi (misal, kebijakan ekspansi fiskal) akan menyebabkan defisit transaksi berjalan (Mankiw, 2007).

A.P. Thirlwall pada tahun 1979 mengusulkan sebuah model yang menjelaskan bahwa tingkat pertumbuhan ekonomi berbeda-beda setiap negara karena adanya perbedaan pada batas kemampuan neraca pembayaran (balance-ofpayments constraints), yang timbul karena perbedaan elastisitas pendapatan ekspor dan impor (Pugno, 1998).

Model Thirlwall merupakan model untuk ekonomi terbuka dimana defisit transaksi berjalan tidak dibiayai dengan utang selamanya dan utang tersebut harus dibayar (Thirlwall, 2001). Model Thirlwall menyimpulkan bahwa tingkat 
pertumbuhan ekonomi dibatasi oleh ketersediaan valuta asing (Moreno-Brid dan Perez, 1992).

Menurut model Thirlwall, dalam jangka panjang sebuah ekonomi tidak dapat tumbuh pada suatu tingkat pertumbuhan yang menghasilkan defisit neraca pembayaran yang semakin membesar. Oleh karena itu, tingkat pertumbuhan keseimbangan tercapai pada saat tingkat pertumbuhan impor sama dengan tingkat pertumbuhan ekspor (Turner, 1999).

Ekonomi Indonesia yang terbuka menyebabkan pertumbuhan ekonomi Indonesia dibatasi oleh kemampuan neraca pembayaran (balance of payments constrained economic growth), sehingga kemampuan investasinya tergantung antara lain dari kemampuan untuk ekspor dan daya tarik Indonesia untuk menarik investasi asing. Berdasarkan model Thirlwall, defisit transaksi berjalan, yang didorong oleh impor barang-barang modal untuk investasi, merupakan citra cermin (mirror image) dari surplus transaksi modal dan finansial, yang mencerminkan investor asing masih tertarik untuk membiayai defisit transaksi berjalan. ${ }^{2}$

Globalisasi ekonomi juga telah mendorong banyak negara mereformasi kebijakan ekonominya dari kebijakan yang berorientasi ke dalam (inward-oriented policies) menuju ke kebijakan yang berorientasi ke luar (outward-looking policies). Kebijakan yang berorientasi ekspor (export-oriented policy) meliputi promosi ekspor secara aktif, mempertahankan keunggulan kompetitif produk-produk utama ekspor, revitalisasi produk ekspor, dan meningkatkan daya saing melalui efisiensi dengan menghilangkan ekonomi biaya tinggi (tumpang tindih regulasi dan korupsi) (Goeltom, 2007).

\section{PEMBAHASAN}

Pembahasan faktor-faktor yang mempengaruhi neraca transaksi berjalan akan dibagi ke dalam beberapa periodisasi dengan menggunakan periodisasi yang digunakan oleh Hill (2000), dengan penyesuaian kondisi terbaru. Hill (2000) mengidentifikasikan empat episode kebijakan dan perkembangan ekonomi Indonesia: (a) rehabilitasi dan pemulihan, 1966-1970; (b) pertumbuhan yang cepat, 1971-1981; (c) penyesuaian terhadap penurunan harga minyak, 1982-1986; dan (d) liberalisasi dan pemulihan, 1987-1996. Episode tersebut tidak termasuk periode selama dan setelah dua krisis besar yaitu krisis keuangan Asia 1997/1998 dan krisis keuangan global 2008/2009.

\footnotetext{
${ }^{2}$ Terima kasih kepada Dr. Indro Bachtiar, Kabid Analisis Sektor Riil, Pusat Kebijakan Ekonomi Makro, Badan Kebijakan Fiskal, Kementerian Keuangan RI, yang telah memperkenalkan konsep BoP constrained growth dan mirror image kepada penulis.
} 


\subsection{Transaksi Berjalan Periode 1960-1979}

Gambar 3.1 menunjukkan perkembangan transaksi berjalan, ekspor, impor dan neraca perdagangan 1960-1979. Defisit transaksi berjalan hampir terjadi setiap tahun kecuali tahun 1974 dan 1979 yang mencatat surplus. Selama periode tersebut, pola transaksi berjalan searah dengan pola neraca perdagangan. Ekspor mulai meningkat pada tahun 1966 dengan pertumbuhan rata-rata tahunan sebesar $29 \%$ untuk periode 1966-1979. Sementara itu, impor mulai tumbuh pesat pada 1967 dengan pertumbuhan rata-rata tahunan sebesar 28\% untuk periode 19671979. Pertumbuhan ekspor yang lebih tinggi dibandingkan impor menyebabkan surplus neraca perdagangan. Menurut Hill (2000) faktor rezim kurs yang realistis yang mendorong kenaikan pesat pada ekspor Indonesia.

Gambar 3.1

Neraca Transaksi Berjalan dan Neraca Perdagangan 1960 - 1979 (US\$ juta)

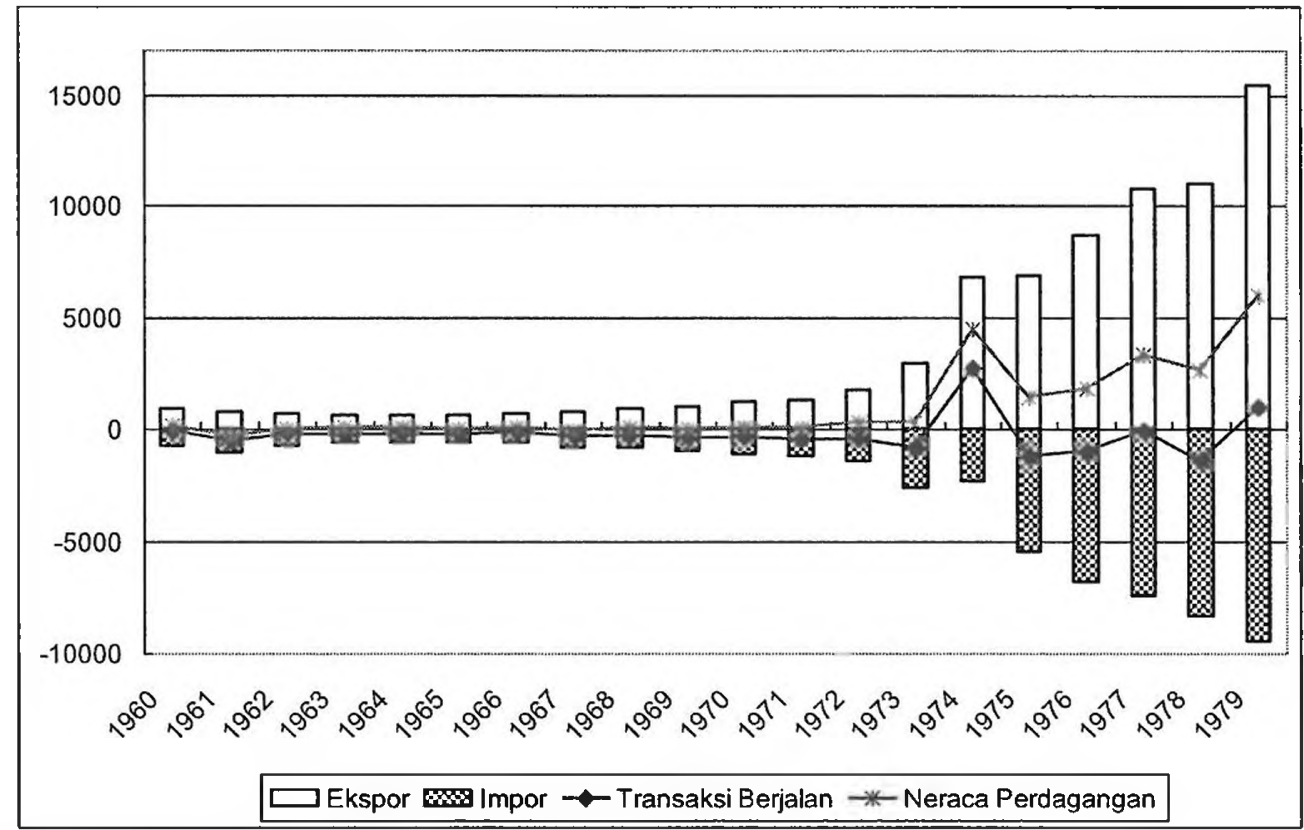

Sumber: Bank Indonesia

Peranan ekspor minyak semakin meningkat dari 30\% pada 1960 , mencapai puncak pada 1975 dengan peranan 74\% kemudian menurun menjadi 64\% pada 1979. Faktor harga minyak dunia sangat menentukan karena selama tahun 1970an OPEC telah menaikkan harga minyak dua kali yaitu pada tahun 1973 dan 1979 (satu tahun setelah pemerintah mendevaluasi rupiah terhadap US\$ sebesar 50\%). Indonesia, sebagai negara pengekspor minyak, memperoleh keuntungan dari harga minyak yang tinggi ini. Ekspor minyak tumbuh sangat signifikan pada 1972-74 
masing-masing sebesar 111\%, 54\%, dan 239\%. Pada tahun 1979 ekspor minyak masih tumbuh cukup bagus sebesar $33 \%$.

Gambar 3.2

Ekspor Minyak dan Bukan Minyak 1960 - 1979 (US\$ juta)

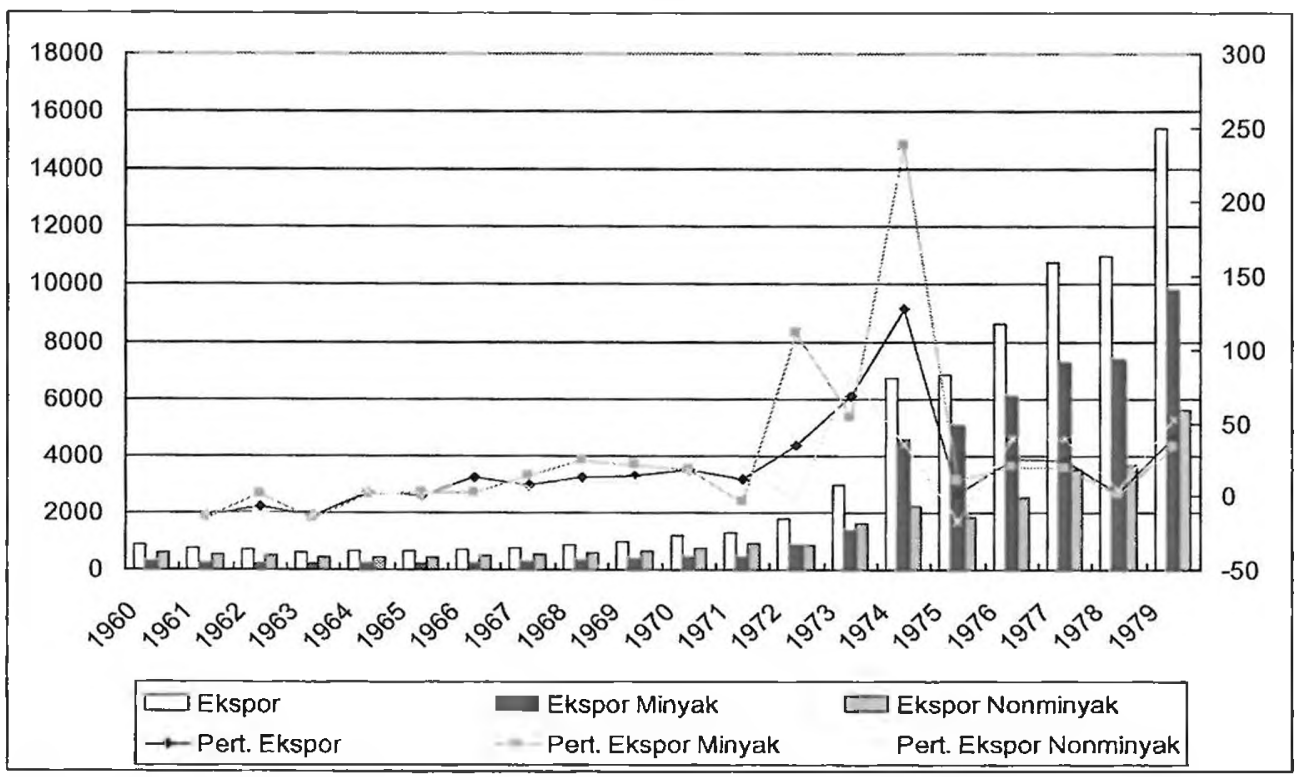

Sumber: Bank Indonesia

Kebijakan pemerintah yang mempengaruhi kinerja transaksi berjalan pada periode ini dapat dijelaskan berikut ini. Indonesia memulai rencana pembangunan lima tahun pada 1969 yang memfokuskan pada pembangunan pertanian. Selama tahun 1970-an harga minyak OPEC mengalami kenaikan dua kali pada tahun 1973 dan 1979 ( yaitu satu tahun setelah pemerintah mendevaluasi kurs Rp/USD sebesar 50\%). Indonesia, sebagai negara pengekspor minyak, mendapat keuntungan dari tingginya harga minyak duni dan menginvestasikan pendapatan pajak minyak pada proyek-proyek pembangunan khususnya irigasi dan infrastruktur fisik, BUMN, serta industri dasar seperti industri baja dan konkrit dalam rangka memperkuat basis industri domestik. Pada saat pemerintah menetapkan sasaran dan melaksanakan kebijakan industrialisasi, pihak swasta juga dilibatkan melalui proyek-proyek investasi skala besar.

\subsection{Transaksi Berjalan Periode 1980-1991}

Melanjutkan surplus tahun 1979, transaksi berjalan masih mencatat surplus pada 1980 akan tetapi untuk sisa tahun lainnya yaitu 1981-1991 transaksi berjalan mencatat defisit. Pola transaksi berjalan masih mengikuti pola neraca perdagangan 
(Gambar 3.3). Pertumbuhan ekspor masih cukup tinggi pada periode ini walaupun pada beberapa tahun yaitu tahun 1982,1983, 1985, dan 1986 ekspor mengalami kontraksi yang cukup dalam dengan pertumbuhan negatif antara $5 \%$ dan $22 \%$. Hal ini diakibatkan oleh turunnya harga minyak pada tahun-tahun tersebut. Begitu pula dengan impor yang masih tumbuh dengan cukup tinggi kecuali pada tahuntahun 1983-86 yang mengalami pertumbuhan negatif. Hal ini disebabkan permintaan domestik yang rendah.

Gambar 3.3

Neraca Transaksi Berjalan dan Neraca Perdagangan 1980 - 1991 (US\$ juta)

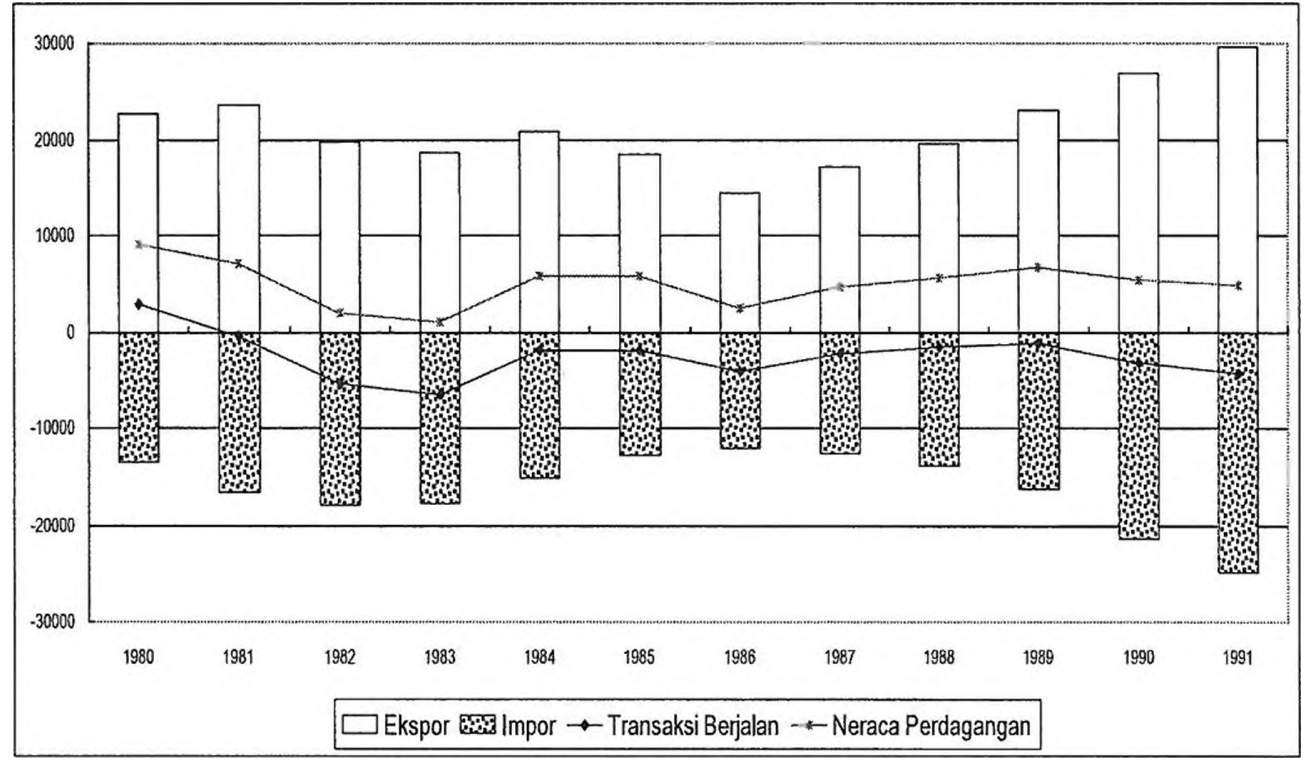

Sumber: Bank Indonesia

Pada awal tahun 1980-an pendapatan minyak mengalami penurunan karena runtuhnya pasar minyak dunia saat harga minyak jatuh pada tahun 1983 dan 1986. Sehingga peranan ekspor minyak terhadap total ekspor mulai mengalami penurunan yaitu dari $64 \%$ pada 1980 menjadi $25 \%$ pada 1991 . Krisis minyak ini menimbulkan tekanan pada neraca pembayaran di mana transaksi berjalan mencatat defisit pada periode 1981-1991. Akan tetapi peranan ekspor gas terhadap total ekspor justru mengalami peningkatan yaitu dari 9\% pada 1980 menjadi $14 \%$ pada 1991 . Untuk mengurangi dampak negatif krisis minyak tersebut terhadap ekonomi nasional, di bidang manajemen nilai tukar, pemerintah mendevaluasi nilai tukar rupiah terhadap US\$ sebanyak dua kali yaitu pada Maret 1983 dan September 1986. 
Gambar 3.4

Ekspor Minyak dan Gas 1980 - 1991

(US\$ juta)

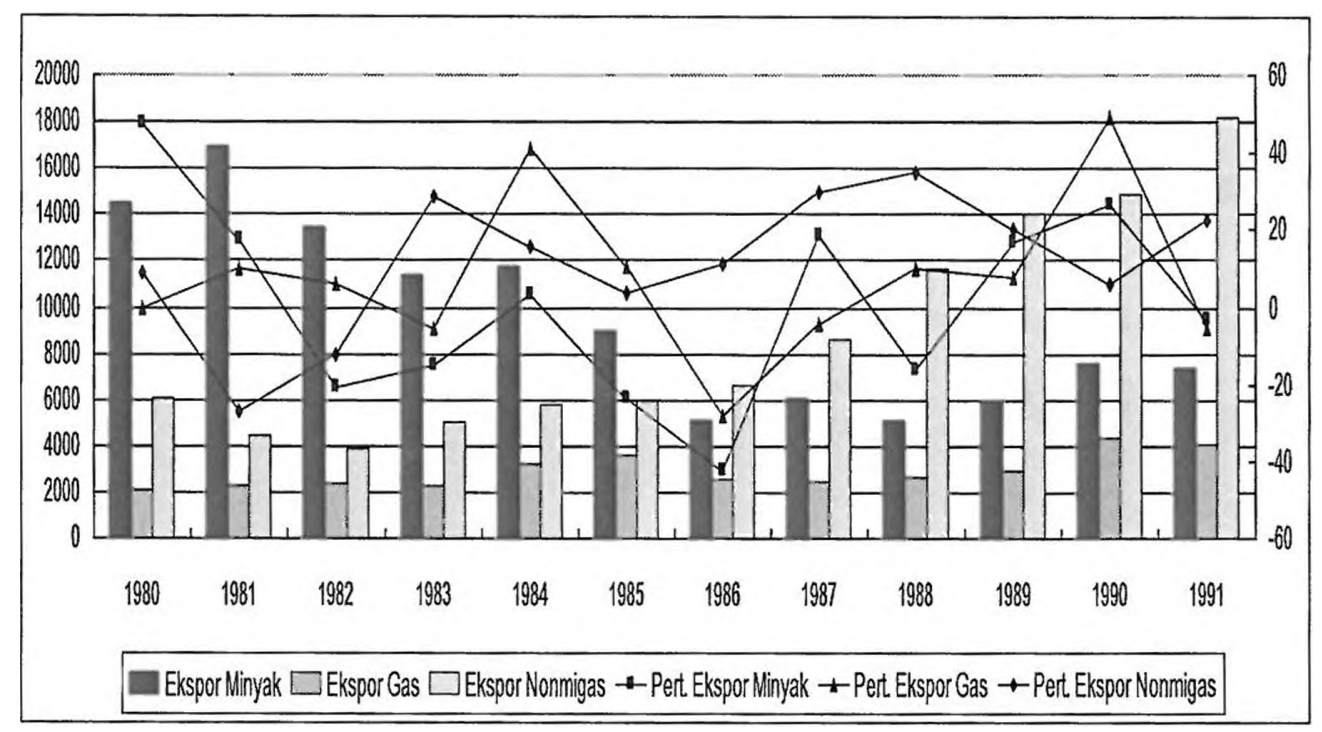

Sumber: Bank Indonesia

Dalam periode ini, cukup banyak kebijakan ekonomi pemerintah yang mempengaruhi kinerja transaksi berjalan. Pada awal tahun 1980-an pendapatan minyak mulai menurun karena jatuhnya harga minyak pada tahun 1983 dan 1986. Krisis minyak ini menimbulkan tekanan pada neraca pembayaran dan mendorong pemerintah untuk mereformasi kebijakan ekonominya. Program penyesuain struktural dan reformasih ekonomi pada tahun 1980-an meliputi empat bidang: (1) manajemen nilai tukar, (2) kebijakan fiskal, (3) kebijakan moneter dan keuangan, dan (4) sektor rill dan perdagangan. Dalam bidang manajemen nilai tukar, pemerintah mendevaluasi kurs Rp/USD pada Maret 1983 dan September 1986. Reformasi kebijakan fiskal meliputi pengurangan belanja subsidi dan pembangunan serta reformasi pajak dengan memperkenalkan PPN dan UU PPh 1983.

Sektor moneter dan finansial direformasi melalui beberapa paket kebijakan. Paket pertama adalah paket Juni 1983 yang menghilangkan batas atas kredit bank, membiarkan suku bunga bergerak mengikuti kekuatan pasar, memberikan peran yang lebih besar kepada bank swasta, menghidupkan kembali pasar saham. Paket Oktober 1988 mereformasi perbankan dan deregulasi dengan menghilangkan hambatan masuk kedalam industri perbankan (Deregulasi perbankan). Paket Desember 1988 mengatur kegiatan lembaga keuangan bukan bank, membolehkan investor asing masuk ke perusahaan sekuritas, dan membatasi perlakuan khusus pada bank investasi BUMN. 
Sektor riil direformasi pada 1986 melalui dua paket. Paket Mei mereformasi kegiatan yang terkait ekspor, seperti penyederhanaan persetujuan investasi, pembebasan bea keluar. Paket Oktober mengganti sistem bukan tarif dengan sistem tarif dan memperbaiki bea masuk dan bea keluar.

\subsection{Transaksi Berjalan Periode 1992-2003}

Transaksi berjalan pada periode ini ditandai oleh Krisis Keuangan Asia yang menyerang Indonesia pada Juli 1997 dan rupiah dibiarkan mengambang pada tahun yang sama. Sebelum Krisis Keuangan Asia 97/98, pemerintah menerapkan kebijakan transaksi berjalan yang defisit untuk mendukung pertumbuhan ekonomi domestik yang sangat pesat dimana selama periode 1992-1996 PDB mengalami pertumbuhan rata-rata $7,3 \%$. Sumber defisit transaksi berjalan bersumber dari surplus neraca perdagangan yang rendah di bawah US $\$ 10$ miliar serta defisit neraca jasa-jasa dan pendapatan. Trauma krisis mendorong negara-negara Asia mengakumulasi cadangan devisa, tanpa kecuali Indonesia dengan menerapkan kebijakan surplus pada transaksi berjalan yang bersumber dari surplus neraca perdagangan (Gambar 3.5).

Gambar 3.5

Komponen Neraca Transaksi Berjalan 1992 - 2003 (US\$ juta)

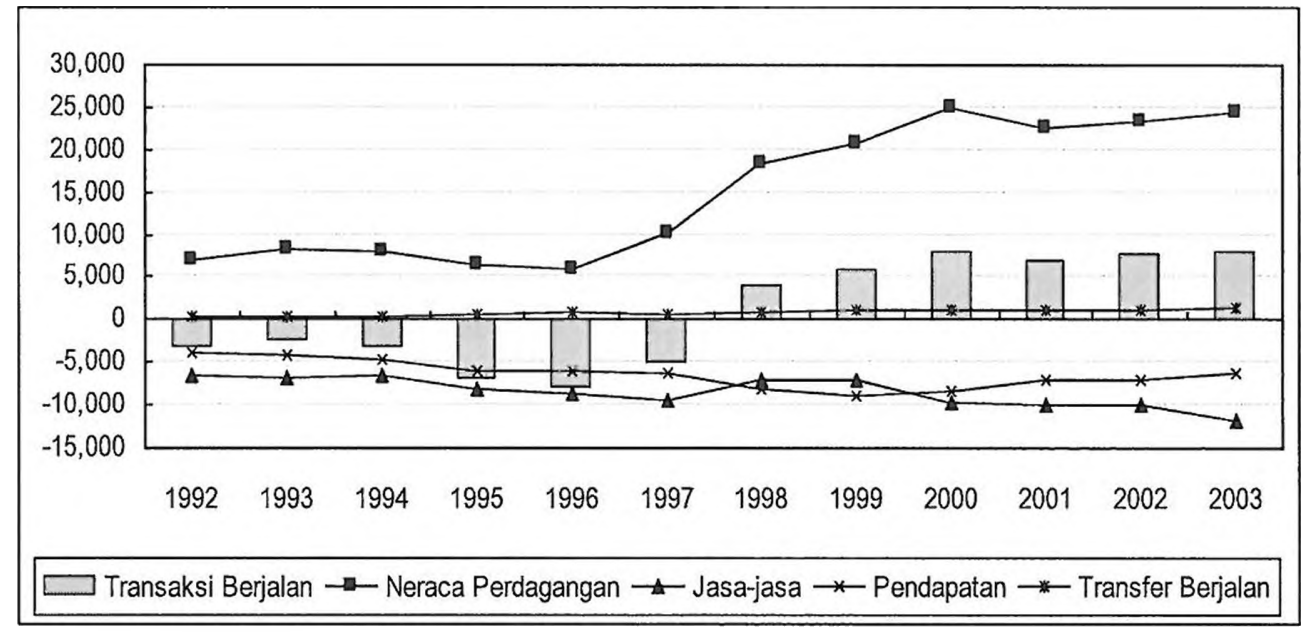

Sumber: Bank Indonesia

Krisis keuangan Asia ini sangat mempengaruhi pertumbuhan ekspor dan impor. Pada awal terjadinya krisis yaitu tahun 1997, ekspor bahkan masih mampu tumbuh sebesar $12 \%$. Pertumbuhan ini dua kali lipat dibandingkan pertumbuhan ekspor tahun 1996. Akan tetapi pada tahun 1998 ekspor mengalami kontraksi sebesar 11\%. Hal ini menunjukkan bahwa walaupun pasar ekspor Indonesia di AS dan Eropa tidak terimbas krisis, pasar ekspor Indonesia di Asia terganggu akibat 
negara-negara Asia ikut terkena krisis. Dampak krisis keuangan Asia terhadap impor Indonesia jauh lebih besar. Pada tahun 1997, impor tumbuh hanya 4\%, turun dari tahun sebelumnya yang tumbuh sebesar 8\%. Pada 1998 impor mengalami pertumbuhan negatif sebesar $31 \%$. Hal ini disebabkan krisis keuangan Asia menyebabkan ekonomi nasional turun sebesar 13,13\% sehingga permintaan domestik turun drastis yang akhirnya berdampak pada pertumbuhan impor yang negatif (Gambar 3.6).

Gambar 3.6

Neraca Transaksi Berjalan dan Neraca Perdagangan 1992 - 2003 (US\$ juta)

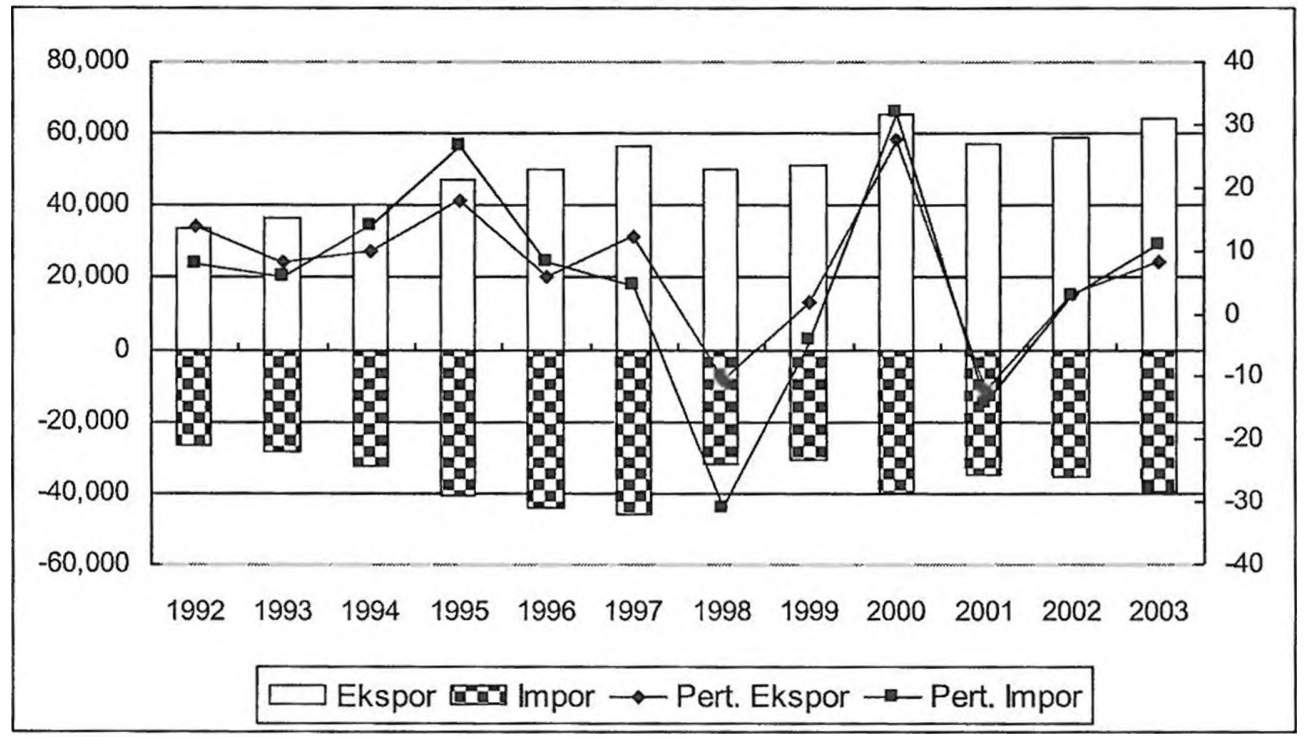

Sumber : Bank Indonesia

Kebijakan yang cukup menonjol yang mempengaruhi kinerja transaksi berjalan dalam kurun waktu 1992-2003 dijelaskan berikut ini. Regulasi di sektor riil adalah terbitnya peraturan pemerintah pada tahun 1994 yang memungkinkan investor asing memperoleh kepemilikan 100\%. Kebijakan desentralisasi fiskal yang diterapkan pada 1 Januari 2001. Kebijakan fiskal melalui UU Keuangan Negara 2003 yang membatasi defisit fiskal maksimun 3\% dari PDB dan keluarnya Indonesia dari program IMF pada tahun yang sama.

\subsection{Transaksi Berjalan Periode 2004-2010}

Transaksi berjalan pada periode ini ditandai oleh beberapa peristiwa penting yaitu pada tahun 2004 Indonesia menjadi negara pengimpor bersih minyak mentah; selama 2005 pemerintah menaikkan harga BBM dua kali. Pertama, pada 1 Maret 2005 harga BBM dinaikkan dengan kenaikan rata-rata 29\% dan kedua, pada 1 Oktober 2005 harga BBM dinaikan dengan kenaikan rata-rata 114\%; 
dan krisis keuangan global yang terjadi pada tahun 2008/2009 serta masih dirasakan hingga 2010 sangat mempengaruhi kinerja transaksi berjalan. Pada periode ini analisis transaksi berjalan dilakukan lebih rinci dengan menggunakan data triwulanan sesuai dengan periode publikasi rutin NPI.

\subsubsection{Neraca Perdagangan}

Gambar 3.7 menunjukkan bahwa neraca perdagangan mencatat surplus selama periode Q1 2004 - Q1 2010 walaupun neraca transaksi berjalan mencatat defsit yaitu pada Q1 2004, Q2 2005, dan Q2-Q4 2008. Yang menarik adalah selama periode defisit transaksi berjalan pertumbuhan ekspor masih positif kecuali pada Q4 2008 dimana ekspor tumbuh negatif $22 \%(\mathrm{q} / \mathrm{q})$ atau $7 \%(\mathrm{y} / \mathrm{y})$.

Walaupun masih dalam periode krisis ekonomi global, neraca perdagangan pada tahun 2009 masih mencatat surplus. Hal ini terjadi karena ternyata impor turun lebih besar dibandingkan ekspor. Pada Q1 2009 impor turun 32\% (q/q) atau $36 \%(y / y)$ sedangkan ekspor turun hanya 19\% (q/q) atau 30\% (y/y). Pemulihan ekspor komoditas dan impor yang relatif rendah karena permintaan domestik yang lemah telah memperbaiki kinerja transaksi berjalan Indonesia. Dengan semakin pulihnya perekonomian dalam negeri, permintaan domestik akan semakin kuat sehingga diperkirakan impor tumbuh lebih cepat daripada ekspor. Akibatnya adalah surplus neraca perdagangan akan berlanjut di bawah tekanan.

Krisis ekonomi global 2008/2009 menyebabkan permintaan global dan harga komoditas melemah sehingga menyebabkan ekspor berkontraksi sebesar $14,4 \%$ pada 2009. Akan tetapi harga minyak mentah yang lebih rendah dan kontraksi investasi dalam negeri telah mengurangi impor sehingga neraca perdagangan tetap surplus pada 2009.

Gambar 3.7

Neraca Transaksi Berjalan dan Neraca Perdagangan Q1 2004 - Q2 2010 (US\$ juta)

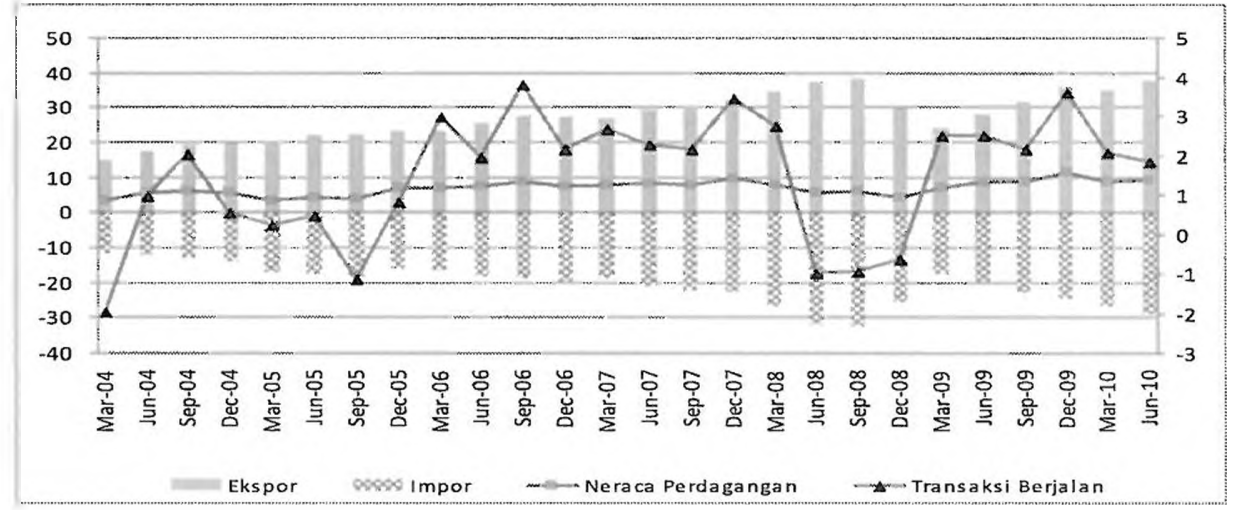

Sumber : Bank Indonesia 
Penguatan permintaan domestik sangat memberikan kontribusi kepada menyempitnya surplus neraca berjalan. Kuatnya permintaan domestik telah menaikkan impor nonmigas dan minyak ke Indonesia, yang menurunkan surplus neraca perdagangan nonmigas (Gambar 3.8) dan neraca perdagangan minyak menjadi defisit (Gambar 3.10). Akan tetapi, surplus neraca perdagangan gas (Gambar 3.11) memperlihatkan kenaikan karena mulai berproduksinya lapangan gas tangguh, dan kenaikan harga minyak dunia menyebabkan transaksi berjalan tetap surplus pada 2009. Neraca perdagangan minyak Indonesia telah defisit karena sebagian besar lapangan minyak adalah lapangan tua dan masih sedikitnya pembukaan lapangan baru. Indonesia telah menjadi pengimpor bersih (net importer) minyak sejak 2004 dan meninggalkan OPEC pada 2008.

Penurunan surplus perdagangan merupakan risiko bagi surplus transaksi berjalan Indonesia. Penurunan ekspor yang terus berlangsung dan kenaikan impor nonmigas dan produk berbasis minyak akan terus menekan surplus perdagangan. Surplus transaksi berjalan Indonesia diperkirakan akan terus mengecil karena kenaikan impor nonmigas yang lebih tinggi daripada impornya.

Gambar 3.8

Neraca Transaksi Berjalan dan Neraca Perdagangan Nonmigas Q1 2004 - Q2 2010 (US\$ juta)

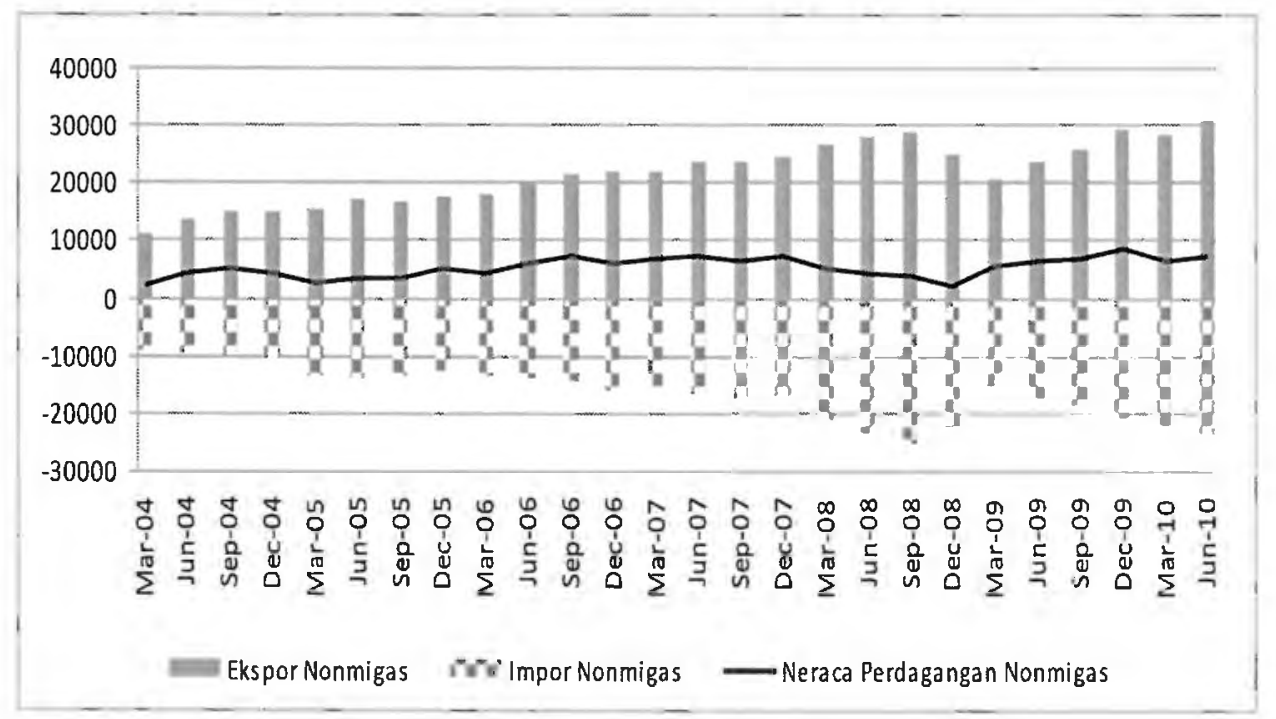

Sumber : Bank Indonesia 


\section{Gambar 3.9 \\ Neraca Transaksi Berjalan dan Neraca Perdagangan Migas Q1 2004 - Q2 2010 (US\$ juta)}

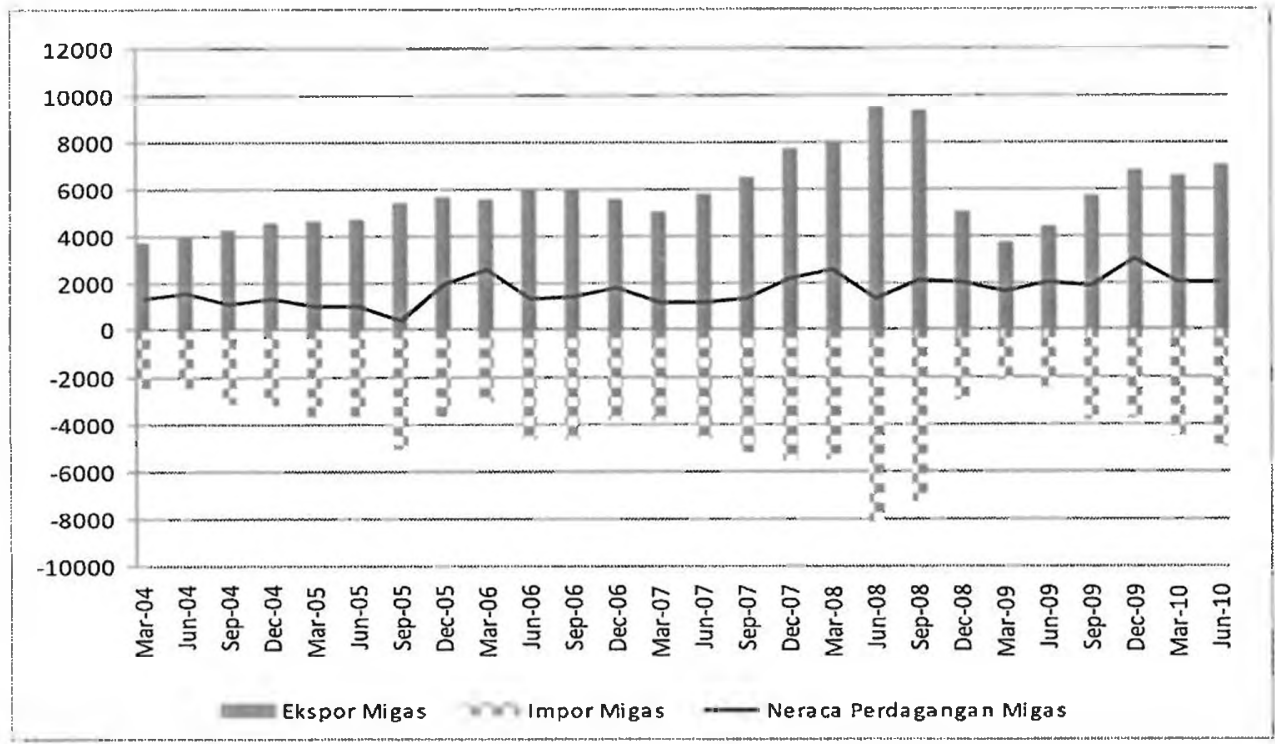

Sumber: Bank Indonesia

Gambar 3.10

Neraca Transaksi Berjalan dan Neraca Perdagangan Minyak Q1 2004 - Q2 2010 (US\$ juta)

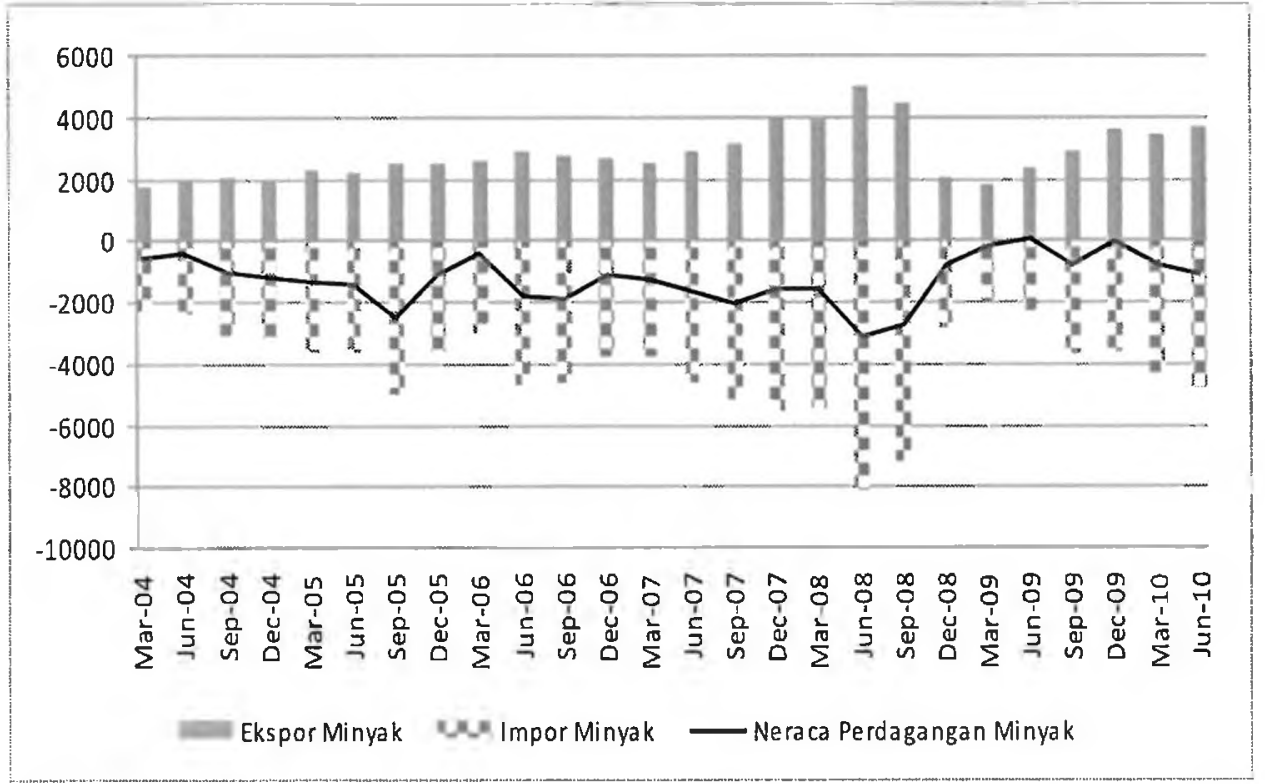

Sumber: Bank Indonesia 
Gambar 3.13 Neraca Transaksi Berjalan dan Pendapatan Q1 2004 - Q2 2010 (US\$ juta)

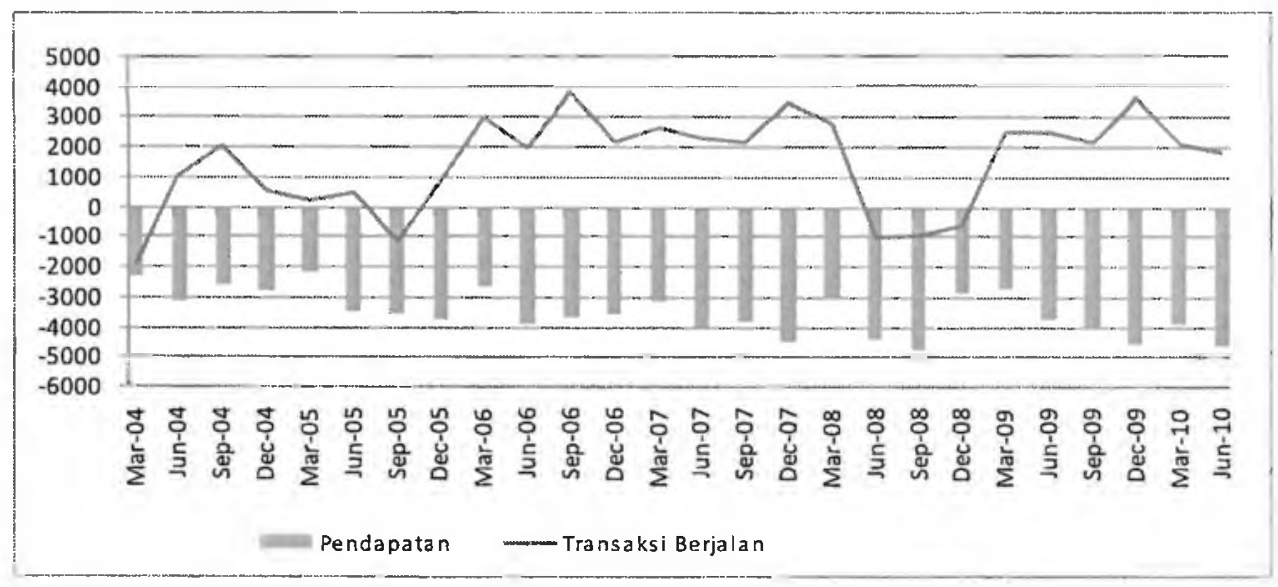

Sumber: Bank Indonesia

\subsubsection{Neraca Transfer Berjalan}

Gambar 3.14 menunjukkan bahwa pola neraca transfer berjalan tidak menyerupai pola neraca transaksi berjalan. Pada triwulan I 2004, triwulan III 2005, triwulan II-IV 2008 neraca transfer berjalan tetap surplus walaupun neraca transaksi berjalan mengalami defisit pada periode tersebut. Hal ini berarti neraca transaksi berjalan mampu bertahan dari krisis keuangan global 2008/2009. Selama periode triwulan I 2004 s.d. triwulan I 12010 transfer berjalan mengalami peningkatan dari US\$306 juta pada triwulan I 2004 menjadi US $\$ 1,2$ miliar pada triwulan I 2010 sehingga neraca transfer berjalan menjadi penyumbang yang cukup penting bagi surplus neraca transaksi berjalan.

\section{Gambar 3.14 Neraca Transaksi Berjalan dan Transfer Q1 2004-Q2 2010 (US\$ juta)}

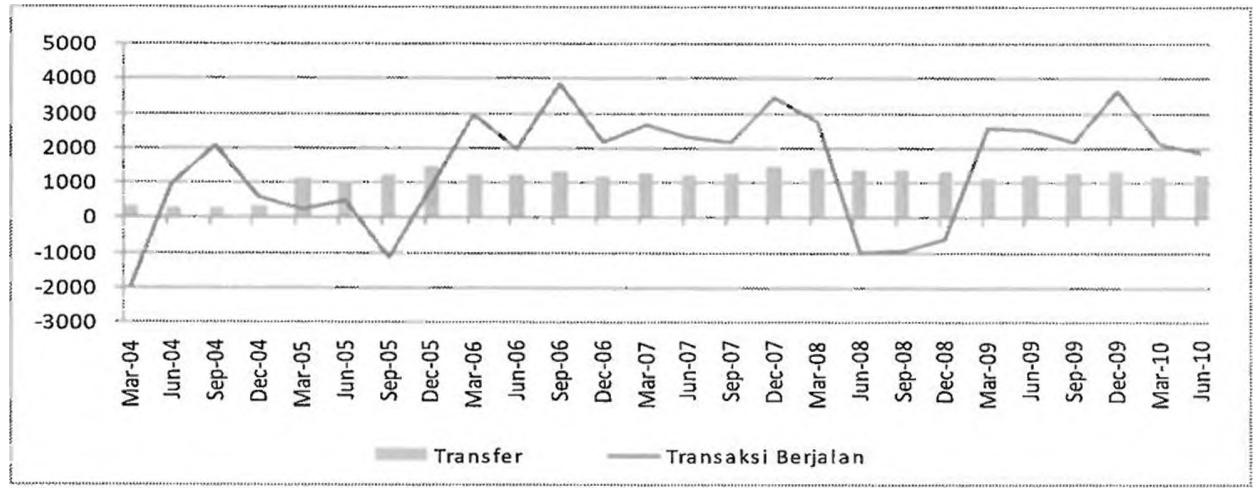

Sumber : Bank Indonesia 
Akan tetapi, karena remitansi tenaga kerja mencerminkan rata-rata $94 \%$ dari neraca transfer berjalan, perlambatan remitansi tenaga kerja merupakan risiko bagi surplus transaksi berjalan Indonesia. Pemulihan ekonomi global yang lambat akan mengurangi arus masuk remitansi tenaga kerja ke Indonesia pada saat pasar tenaga kerja global masih belum pulih.

\subsection{Pengaruh PDB Domestik}

PDB domestik mempengaruhi transaksi berjalan melalui impor yang mencerminkan permintaan domestik akan produk impor. Hubungan antara transaksi berjalan (\% PDB) dengan pertumbuhan PDB disajikan pada Gambar 3.15 Terdapat hubungan negatif antara transaksi berjalan dan pertumbuhan PDB domestik. Ini berarti bahwa pertumbuhan PDB domestik yang tinggi akan mendorong defisit transaksi berjalan melalui kenaikan impor barang dan jasa.

Gambar 3.15

Hubungan Transaksi Berjalan dan Pertumbuhan Ekonomi Domestik

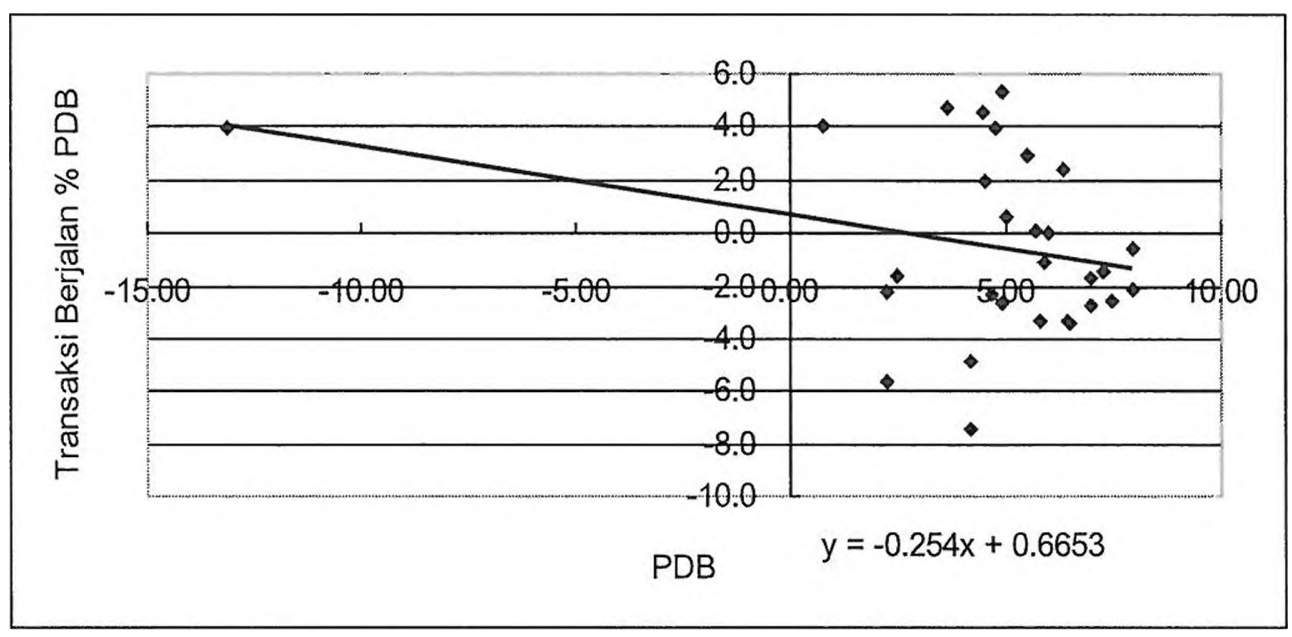

Sumber: BPS, World Bank, \& Bank Indonesia.

\subsection{Pengaruh PDB Dunia}

PDB dunia mempengaruhi transaksi berjalan melalui ekspor karena PDB dunia mencerminkan permintaan dunia terhadap produk ekspor Indonesia. Hubungan antara transaksi berjalan dengan PDB dunia disajikan pada Gambar 3.16 yang menunjukkan terdapat hubungan positif antara PDB dunia dengan transaksi berjalan. Ini berarti kenaikan PDB dunia dapat menopang surplus transaksi berjalan melalui kenaikan permintaan produk ekspor Indonesia. 
Gambar 3.16

Hubungan Transaksi Berjalan dan Pertumbuhan Ekonomi Dunia

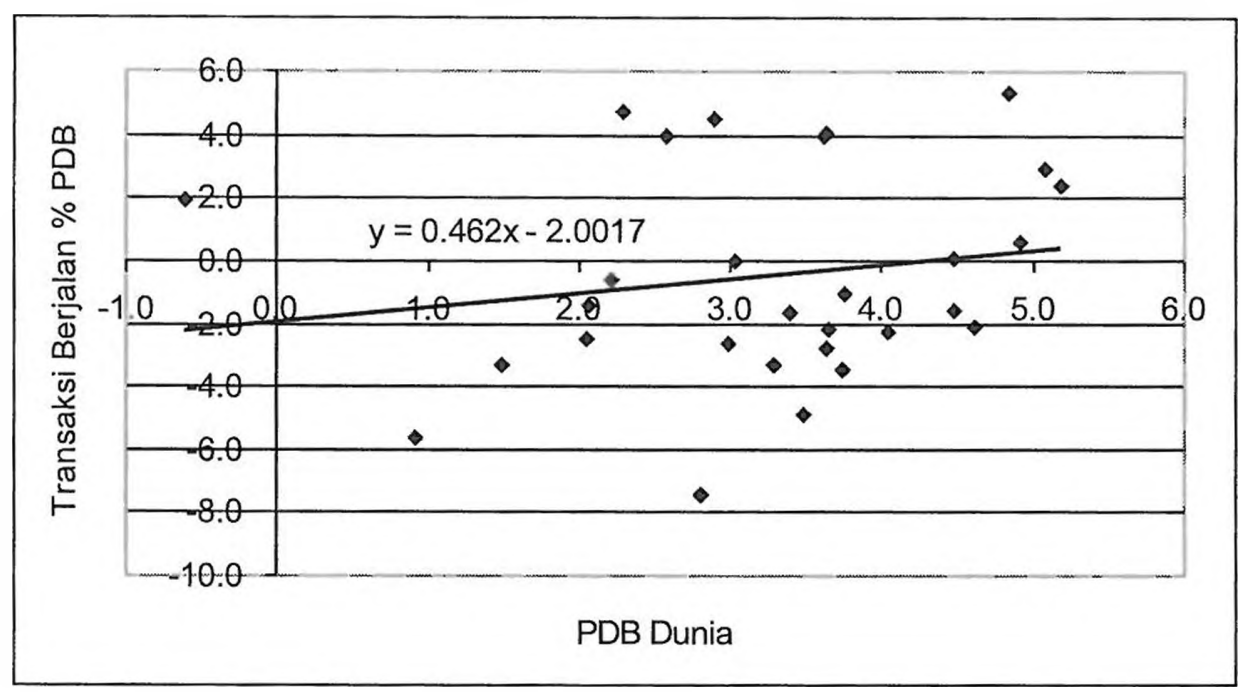

Sumber: IMF, World Bank, \& Bank Indonesia.

\subsection{Pengaruh Harga Komoditas}

Indonesia adalah negara pengekspor bersih sumber daya alam, sehingga fluktuasi harga komoditas internasional akan sangat berpengaruh terhadap kinerja neraca transaksi berjalan. Kenaikan harga komoditas global akan memperbaiki kinerja neraca transaksi berjalan sedangkan penurunan harga akan memperburuk kinerja. Misalkan dampak kenaikan harga minyak dunia adalah setiap US\$1 kenaikan harga akan mengakibatkan penerimaan dari ekspor minyak naik sebesar volume ekspor (juta barel) dikalikan US\$1, dan penerimaan dari ekspor gas juga naik karena harga gas dikaitkan dengan harga minyak yaitu sebesar volume ekspor (Millions British Thermal Unit/Metric Ton) dikalikan kenaikan harga gas. Akan tetapi pengeluaran untuk impor minyak baik BBM atau minyak mentah juga naik yaitu volume impor dikalikan dengan harga impor. Menurut Bank Indonesia setiap kenaikan harga minyak sebesar US\$1 per barrel diperkirakan akan meningkatkan cadangan devisa sebesar 145 juta dollar AS sejalan dengan surplus transaksi berjalan." (Abdullah 2007). Sementara itu, simulasi Bank Indonesia yang lain menunjukkan bahwa untuk setiap kenaikan US\$1 per barel, pada Q4 2007 akan meningkatkan surplus transaksi berjalan US\$23,3 juta dan meningkatkan cadangan devisa US $\$ 36,3$ juta setiap triwulannya dengan asumsi permintaan konsumsi minyak domestik sebesar 396,2 juta barel (Antara 2007). Kemudian berdasarkan wawancara penulis dengan staf Bank Indonesia menunjukkan bahwa setiap kenaikan US\$1 diperkirakan akan menaikkan surplus transaksi berjalan dan cadangan devisa berkisar US $\$ 40-50$ juta tiap triwulan. Perbedaan ini dapat 
dimaklumi karena adanya perbedaan dalam sensitivitas ekspor dan impor terhadap harga untuk setiap periode.

Gambar 3.17

Transaksi Berjalan dan Harga Komoditas 1980-2009

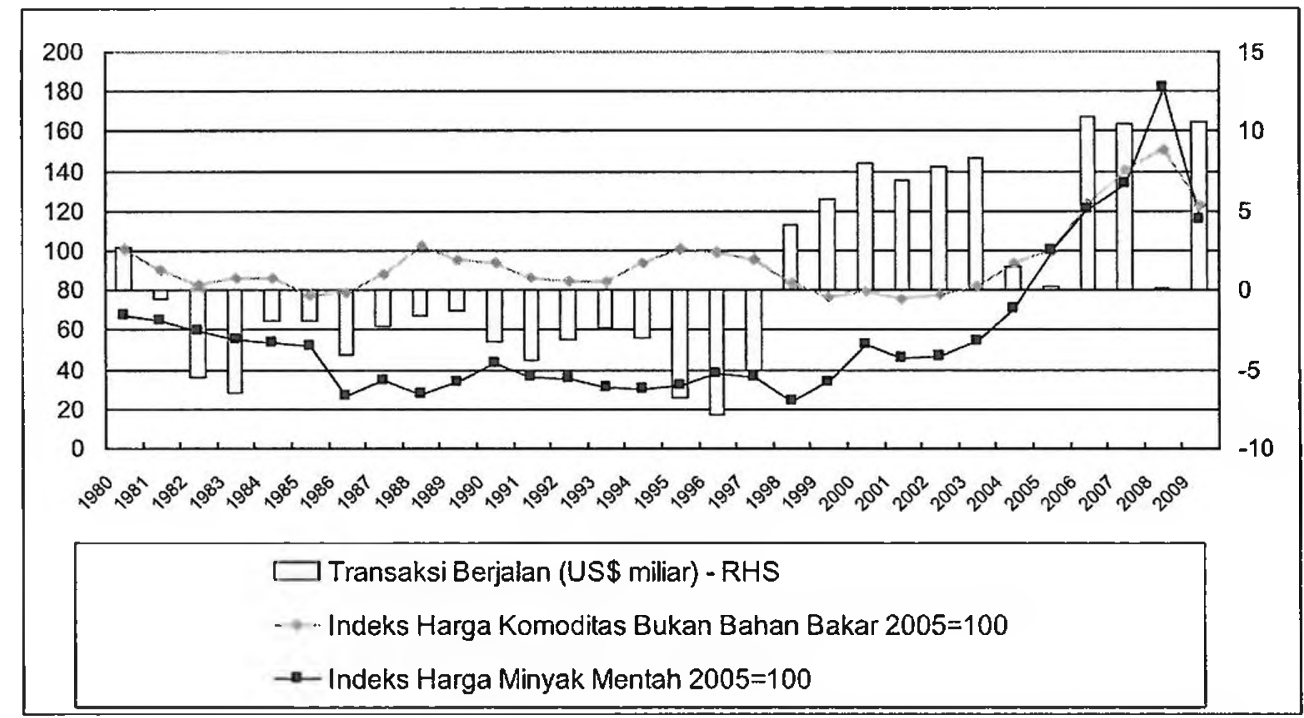

Sumber: Bank Indonesia dan IMF.

\subsection{Pengaruh Nilai Tukar terhadap Transaksi Berjalan}

Perkembangan nilai tukar rupiah terhadap US\$ selama periode 1967-2009 disajikan pada Gambar 3.18. Menurut Hofman, Zhao and Ishihara (2007), Indonesia menggunakan manajemen nilai tukar yang aktif sebagai kebijakan ekonomi makro. Setelah melepas sistem nilai tukar jamak dan mengadopsi nilai tukar yang konsisiten pasar pada 1970, Indonesia mematok ( $p e g$ ) rupiah terhadap US\$ pada 1971 (Hill 2000) dan pada 1978 Bank Indonesia melepas sistem patok (pegged system) dan mengadopsi nilai tukar mengambang terkelola (managedfloating). Karena defisit transaksi berjalan yang besar dan untuk mempertahankan daya saing di pasar internasional, pemerintah mendevaluasi rupiah terhadap US\$ tiga kali yaitu pada November 1978, Maret 1983 dan September 1986 dan rupiah terdepresiasi masing-masing sekitar 50\%, 28\%, dan 45\% (Hill 2000). Devaluasi ini membuahkan hasil yang ditunjukkan oleh surplus transaksi berjalan pada 1979 dan 1980 serta penurunan defisit transaksi berjalan pada tahun-tahun 1987-1989. 
Gambar 3.18

Transaksi Berjalan dan Nilai Tukar Rp/US\$ 1967-2009

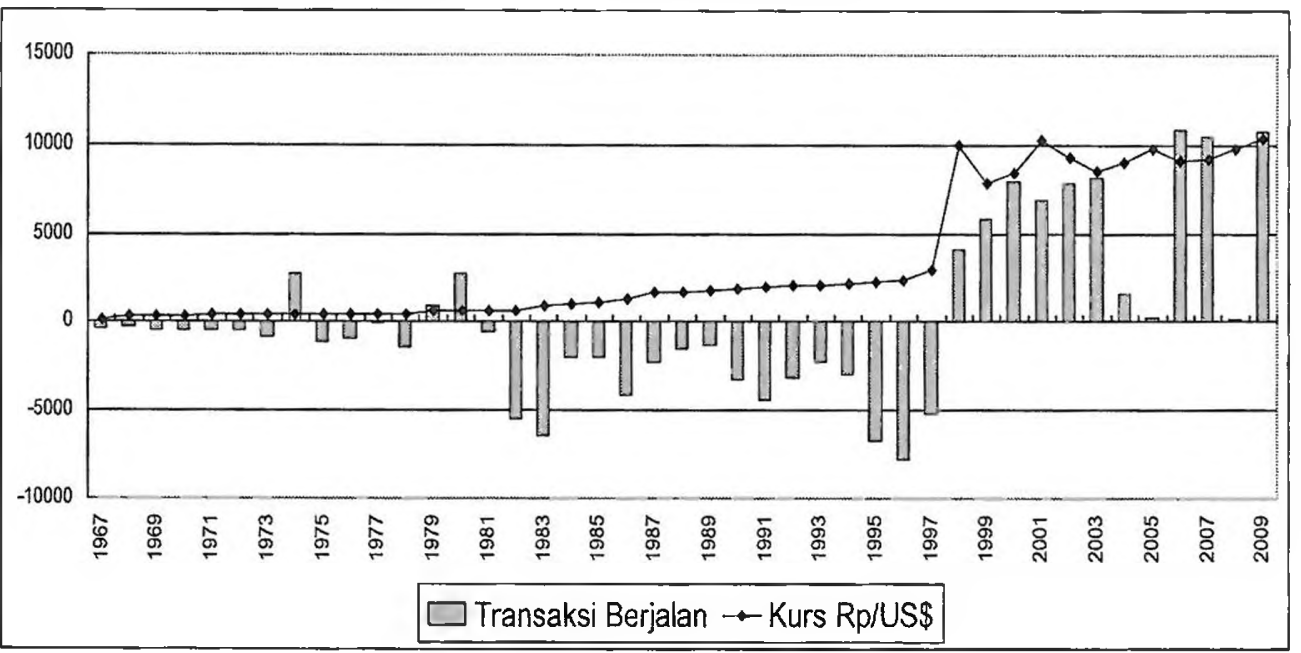

Sumber: Bank Indonesia

Setelah 1986 nilai tukar relatif stabil dan tidak ada kebijakan devaluasi yang diambil. Sejak awal 1990-an Bank Indonesia mempertahankan stabilitas rupiah dengan mengelola pegerakan rupiah terhadap sekeranjang mata uang (Hill 2000). Setelah rupiah stabil selama sepuluh tahun, nilai tukar rupiah terhadap US\$ menjadi terlalu kuat (overvalued). Sehingga, selama krisis keuangan Asia 1997, Bank Indonesia tidak dapat mempertahankan kestabilan rupiah. Pada pertengahan Agustus 1997, Bank Indonesia mengakhiri pita intervensi nilai tukar yang diadopsi pada 1992 dan melaksanakan rezim nilai tukar mengambang bebas (free floating exchange rate system) (Nasution 1999). Sistem nilai tukar ini telah memperbaiki kinerja transaksi berjalan pasca krisis yang mencatat suplus yang cukup besar sehingga cadangan devisa terus bertambah.

\section{PENUTUP}

\subsection{Kesimpulan}

Kinerja transaksi berjalan Indonesia selama periode 1960-2010 mengalami pasang surut yang sangat dipengaruhi baik oleh faktor internal (kondisi ekonomi domestik) maupun faktor eksternal (perkembangan ekonomi dunia). Secara umum, beberapa faktor yang dapat mempengaruhi kinerja transaksi berjalan adalah pertumbuhan ekonomi dunia, pertumbuhan mitra dagang utama Indonesia, pertumbuhan ekonomi domestik, harga komoditas, nilai tukar, serta krisis keuangan. Kebijakan ekonomi yang diambil pemerintah juga mempengaruhi kinerja transaksi berjalan. 
Pertumbuhan ekonomi dunia terutama pertumbuhan mitra dagang utama Indonesia mempengaruhi kinerja transaksi berjalan melalui ekspor barang dan jasa, sedangkan pertumbuhan ekonomi domestik melalui impor barang dan jasa. Harga komoditas mempengaruhi kinerja transaksi berjalan baik melalui ekspor karena Indonesia adalah eksportir komoditas, maupun impor karena Indonesia saat ini menyandang status net oil importer. Kinerja transaksi berjalan dipengaruhi oleh kebijakan nilai tukar melalui daya saing harga produk-produk Indonesia di pasar global.

Dua krisis keuangan memberikan dampak yang berbeda terhadap kinerja transaksi berjalan. Krisis keuangan Asia 97/98 memberikan pelajaran tentang pentingnya memiliki cadangan devisa yang besar melalui kebijakan surplus transaksi berjalan. Krisis keuangan global 08/09 memberikan tekanan cukup besar pada transaksi berjalan dimana pasar ekspor utama Indonesia mengalami resesi sehingga permintaan ekspor turun drastis, sedangkan permintaan impor masih tinggi yang bersumber dari permintaan domestik.

\subsection{Rekomendasi Kebijakan}

Dengan kondisi surplus transaksi berjalan saat ini, Indonesia dapat meningkatkan investasinya dengan menggunakan tabungan domestik. Akan tetapi untuk mencapai pertumbuhan investasi yang lebih tinggi lagi, Indonesia memerlukan arus masuk modal asing karena tabungan domestik tidak akan mencukupi untuk menopang pertumbuhan investasi yang lebih tinggi agar tercipta lebih banyak lapangan kerja. Hal ini akan memiliki konsekuensi defisit transaksi berjalan. Akan tetapi sepanjang terdapat arus masuk bersih modal asing yang meningkatkan investasi dan pertumbuhan ekonomi, Indonesia dapat mempertahankan defisit transaksi berjalan yang aman.

Selain itu, kebijakan surplus transaksi berjalan akan menyebabkan akumulasi cadangan devisa yang semakin besar. Jika terjadi krisis finansial, cadangan devisa yang cukup besar diharapkan dapat mempertahankan stabilitas nilai tukar. Akan tetapi, pada kondisi normal, akumulasi cadangan devisa yang besar memiliki konsekuensi biaya kesempatan (opportunity cost) yang tidak murah. Oleh karena itu, pemerintah harus bisa mengestimasi berapa tingkat cadangan devisa yang memadai sesuai dengan perkembangan kondisi ekonomi. Kemudian, manajemen cadangan devisa harus lebih proaktif untuk mengurangi dampak biaya kesempatan. 


\section{DAFTAR PUSTAKA}

Abdullah, Burhanuddin, "Upaya Memastikan Ketidakpastian" Kompas, 25 Oktober 2007.

Antara, "Harga Minyak Berpotensi Turunkan Pertumbuhan Ekonomi 2008"Antara, 2007.

http://www.bphmigas.go.id/p/bphmigaspages/modules/news/news_0499.html?uri=/b

phmigaspages/berita.html

Ardiyanto, Ferry, "Analysis of Current Account Deficits and Fiscal Deficits in Indonesia: A VAR Approach," Jurnal Keuangan Publik, Vol. 4, No. 2, September 2006, hal. 1 - 18.

Bank Indonesia, Neraca Pembayaran Indonesia dan Posisi Investasi Internasional Indonesia: Konsep, Sumber Data, dan Metode, Jakarta: Direktorat Statistik Ekonomi dan Moneter, Bank Indonesia, 2008.

Calderón, César, Alberto Chong, dan Norman Loayza, "Determinants of Current Account Deficits in Developing Countries," Policy Research Working Paper No. 2398, Washington, DC, USA: International Monetary Fund, 2000.

Carbaugh, Robert J., "International Economics," Eleventh Edition, Ohio: Thomson SouthWestern, 2008.

Goeltom, Miranda S., Essays in Macroeconomic Policy: The Indonesian Experience, Jakarta: PT Gramedia Pustaka Utama, 2007.

International Monetary Fund (IMF), Balance of Payments Textbook, Washington, DC, USA: IMF, 1996.

Mankiw, N.G., Macroeconomics, Sixth Edition, New York: Worth Publishers, 2007.

Moreno-Brid, J.C. dan Perez, E., Balance-of-Payments-Constrained Growth in Central America: 1950-96, Journal of Post Keynesian Economics, Fall 1999, Vol. 22, No. 1, hal. 131.

Pugno, Maurizio, The Stability of Thirlwall's Model of Economic Growth and the Balance-ofPayements Constraint, Journal of Post Keynesian Economics, Summer 1998, Vol. 20, No. 4, hal. 559.

Thirlwall, A.P., The Relation between the Warranted Growth Rate, the Natural Rate, and the Balance of Payments Equilibirium Growth Rate, Journal of Post Keynesian Economics, Fall 2001, Vol. 24, No. 1, hal. 81.

Turner, P. The Balance of Payments Constraint and the Post 1973 Slowdown of Economic Growth in the G7 Economies, International Review of Applied Economics, Vol. 13, No. 1,1999 , hal. 41 . 